*akls View/Frint Document Cover Sheet tow

This document was retrieved from the Boeing ISEARCH System.

Accession \#: D196054778

Document \#: SD-WM-ER-445

Title/Desc:

TANK 241C107 HEADSPACE GAS \& VAPOR CHARACTERIATION RESULTS FOR SAMPLES COLLECTED IN 9/1994 


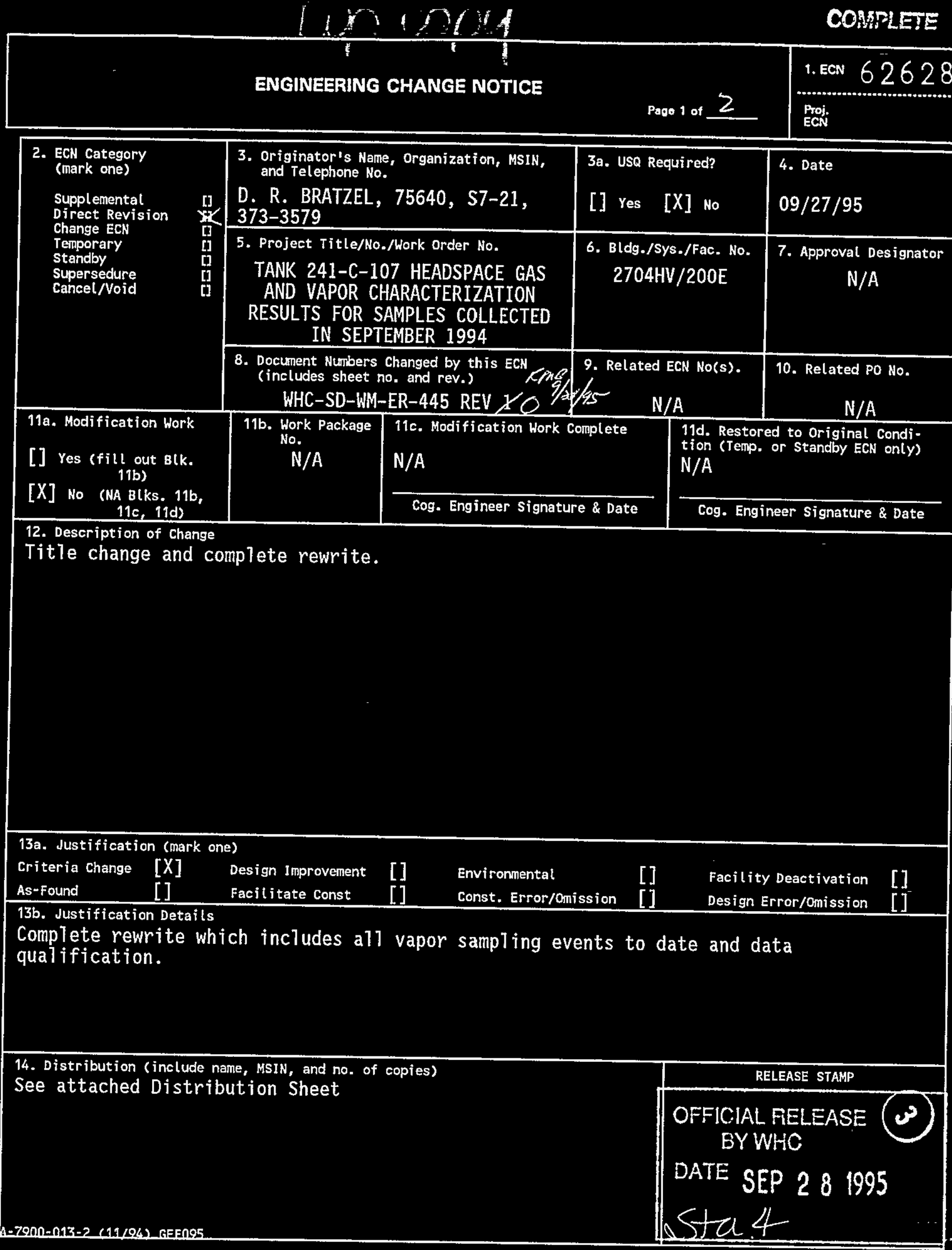




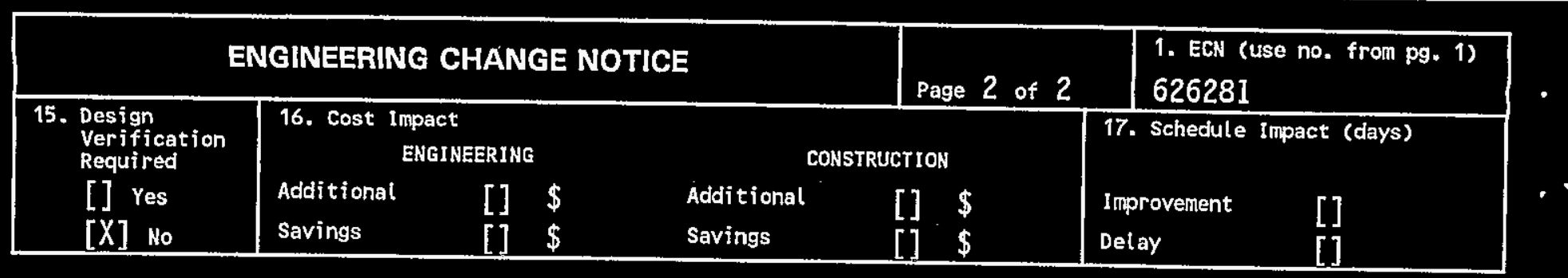

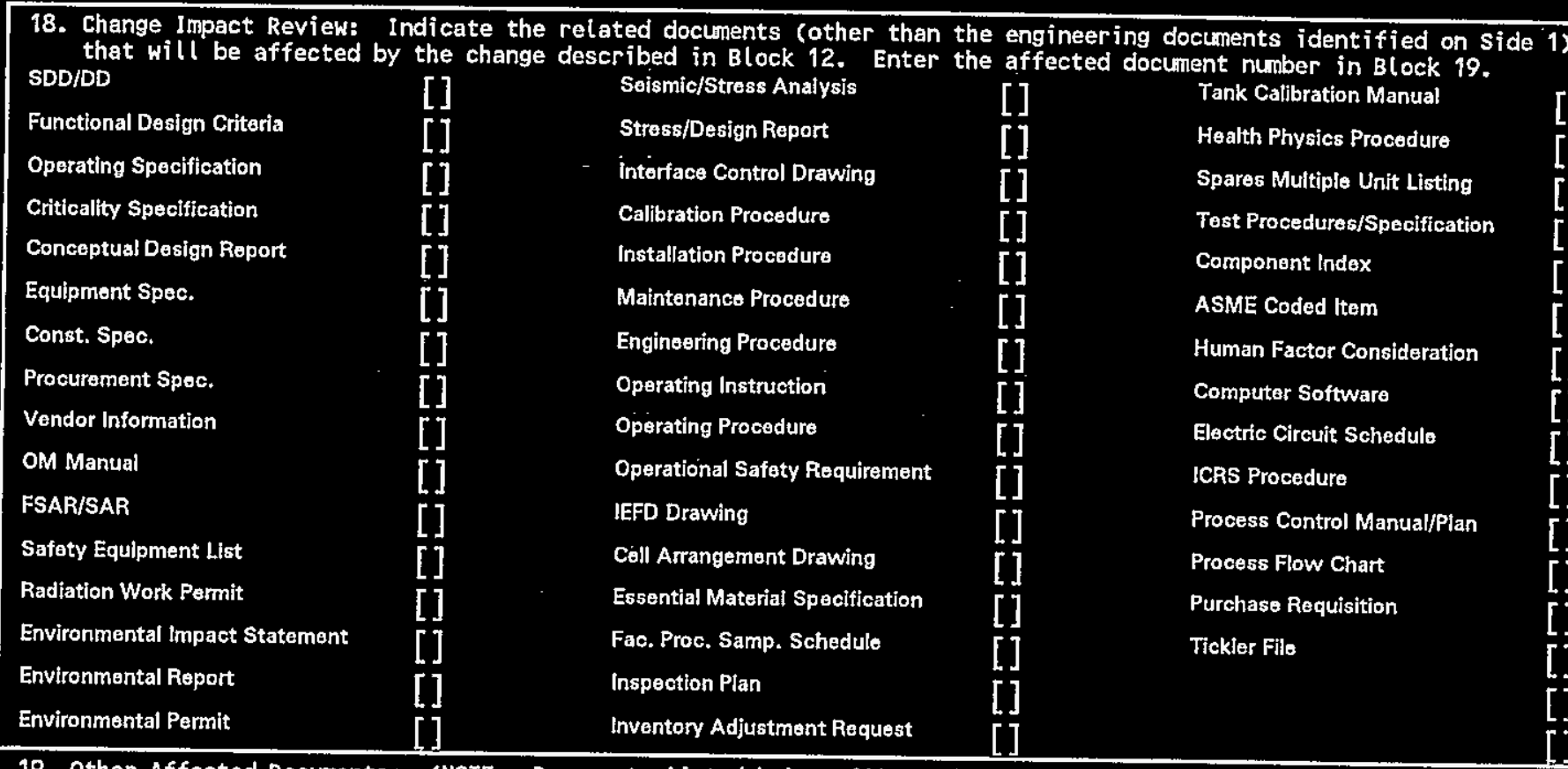

19. Other Affected Documents: (NorE: Documents (isted below will not be revised by this ECN.) Signatures below indicate that the signing organization has been notified of other affected documents (isted below. Document Number/Revision Document Number/Revision

Document Number Revision

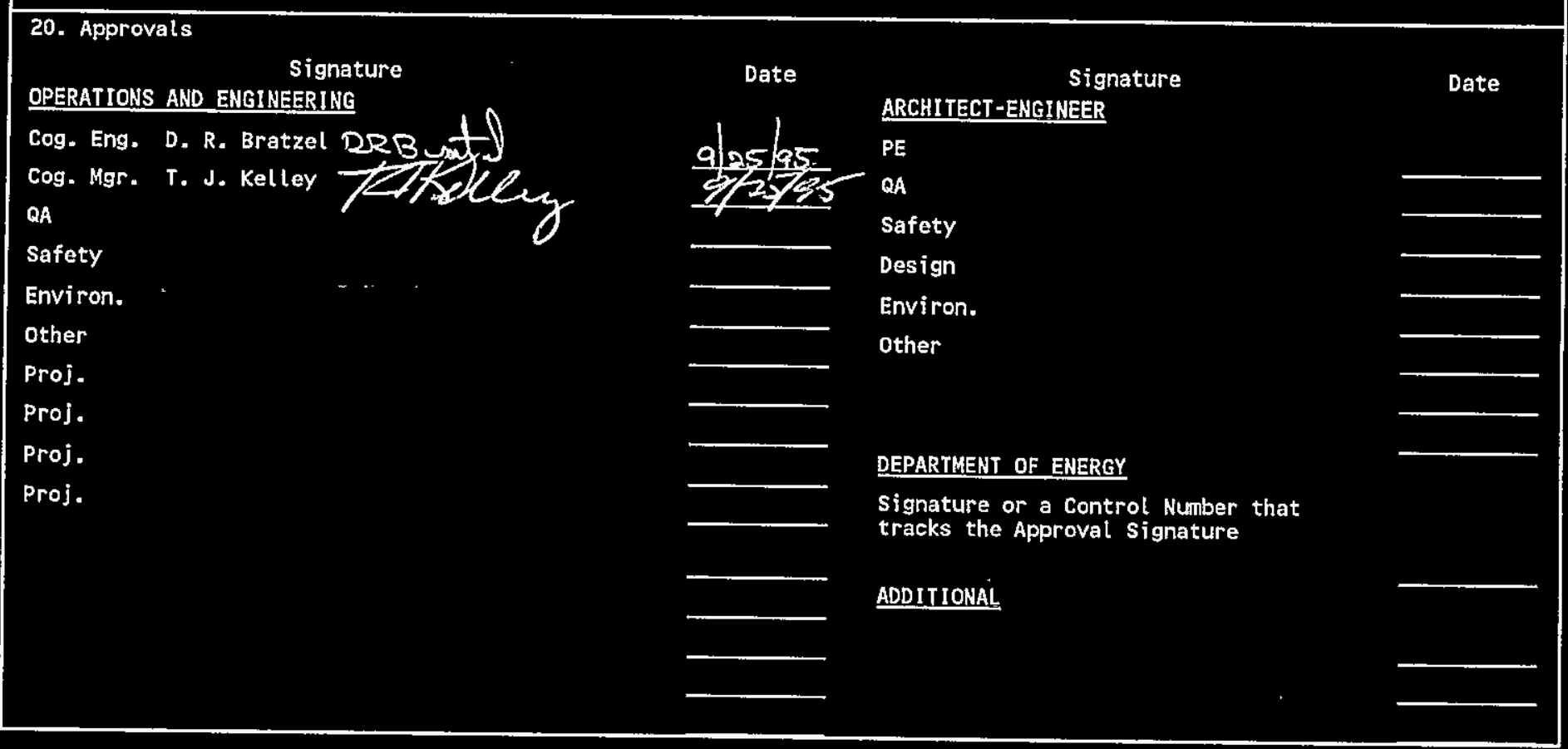




\section{RELEASE AUTHORIZATION}

Document Number: $\quad$ HHC-SD-WM-ER-445, REV 1

Document Title: Tank 241-C-107 Headspace Gas and Vapor

Characterization Results for Samples Collected in

September 1994

Release Date: $\quad 9 / 28 / 95$

This document was reviewed following the procedures described in WHC-CM-3-4 and is:

APPROVED FOR PUBLIC RELEASE

WHC Information Release Administration Specialist:
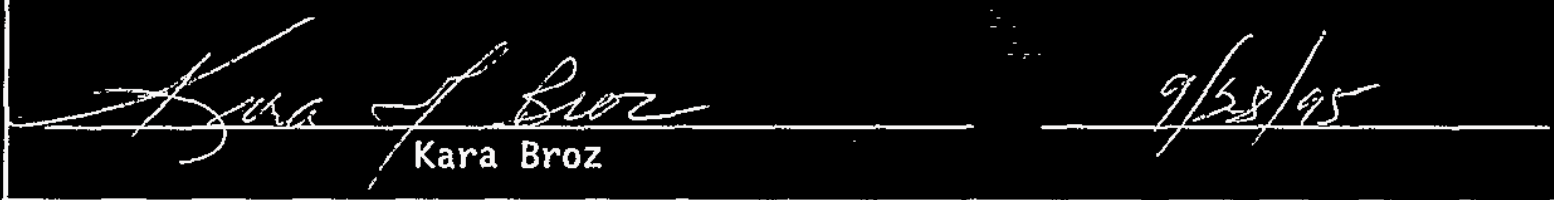

TRADEWARK DISCLATWER. Reference herein to any specific commercial product, process, or service by trade name, trademark, manufacturer, or otherwise, does not necessarily constitute or imply its endorsement, recommendation, or favoring by the United States Government or any agency thereof or its contractors or subcontractors.

This report has been reproduced from the best available copy. Available in paper copy. Printed in the United States of America. To obtain copies of this report, contact:

Westinghouse Hanford Company - Document Control Services

P.0. Box 1970, Mailstop H6-08, Richland, WA 99352

Telephone: (509) 372-2420; Fax: (509) 376-4989 
<smiles>C1CC1</smiles> 
2. Title

TANK 241-C-107 HEADSPACE GAS AND VAPOR CHARACTERIZATION RESULTS FOR SAMPLES COLLECTED IN SEPTEMBER 1994

5. Key Words

CHARACTERIZATION OBJECTIVES, TANK HEADSPACE, SAMPLING EVENT, INORGANIC GASES, ORGANIC VAPORS
3. Number

NHC-SD-WH-ER-445
4. Rev No.

1

\section{Author}

Name: D. R. BRATZEL

signature

Organization/Charge code $75640 / \mathrm{N} 4 \mathrm{AB} 1$

\section{Abstract}

Significant changes have been made to all of the original vapor characterization reports. This report documents specific headspace gas and vapor characterization results for all vapor sampling events to date. In addition, changes have been made to the original vapor reports to qualify the data based on quality assurance issues associated with the performing laboratories.

8.

RELEASE STAMP

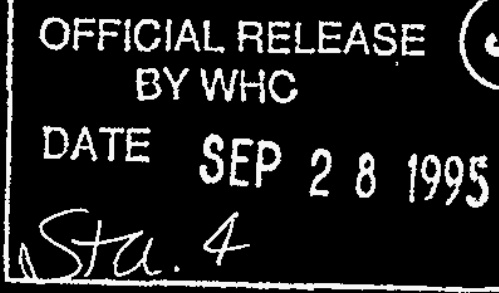


b 


\begin{tabular}{|c|c|c|c|c|}
\hline \multicolumn{2}{|r|}{ RECORD OF REVISION } & \multicolumn{2}{|c|}{$\begin{array}{l}\text { (1) Document Number } \\
\text { WHC-SD-WM-ER-445 }\end{array}$} & Page 1 \\
\hline \multicolumn{5}{|c|}{$\begin{array}{l}\text { (2) Title } \\
\text { TANK 241-C-107 HEADSPACE GAS AND VAPOR CHARACTERIZATION RESULTS FOR SAMPLES COLLECTED } \\
\text { IN SEPTEMBER } 1994\end{array}$} \\
\hline \multicolumn{5}{|c|}{ CHANCE, CONTROL RECORD } \\
\hline (3) Revision & (4) Description of Change - Replace, Add, and Delete Pages & \multicolumn{3}{|c|}{ Authorized for Release } \\
\hline 0 & $\begin{array}{l}\text { (7) WHC-SD-WM-ER-445, REV. 0, EDT } 612337 \\
\text { May } 31,1995\end{array}$ & (5) Cog. Engr. & (6) $\mathrm{c}$ & Mgr. Date \\
\hline I RS & $\begin{array}{l}\text { Complete revision and title change. ECN } \\
626281\end{array}$ & PRBAt & & $\log _{7} 9 / 25$ \\
\hline & & & & 7 \\
\hline & & & & \\
\hline & & & & \\
\hline & & & & \\
\hline & & & & \\
\hline & & & & \\
\hline & & & & \\
\hline & & & & \\
\hline & & & & \\
\hline & & & & \\
\hline & & & & \\
\hline & & & & \\
\hline
\end{tabular}




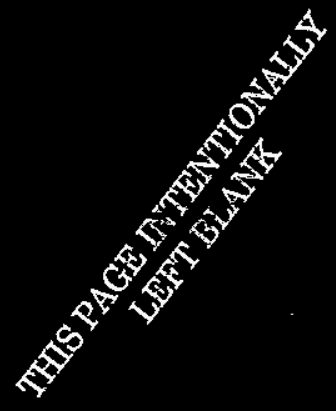




\title{
Tank 241-C-107 Headspace Gas and Vapor Characterization Results for Samples Collected in September 1994
}

\author{
J. L. Huckaby \\ Pacific Northwest Laboratories \\ D. R. Bratzel \\ Westinghouse Hanford Company
}

Date Published

September 1995

Prepared for the U.S. Department of Energy Office of Environmental Restoration and Waste Management

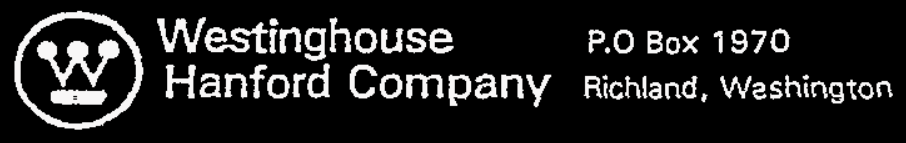

Management and Operations Contractor for the 


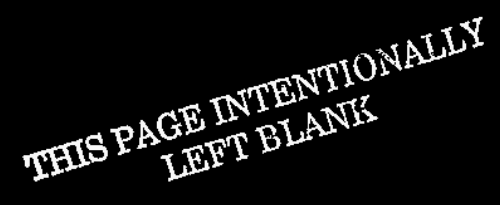




\section{Contents}

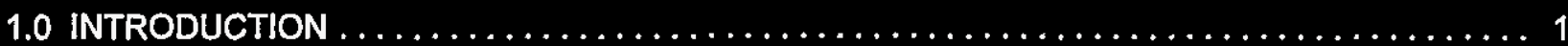

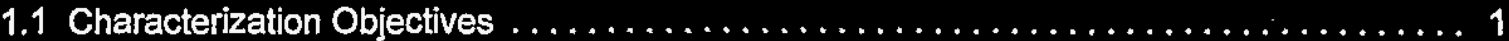

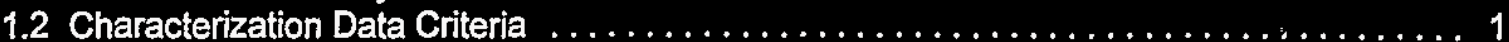

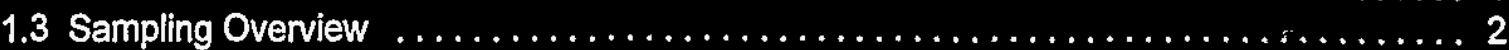

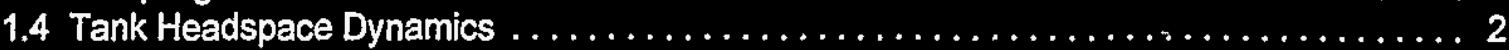

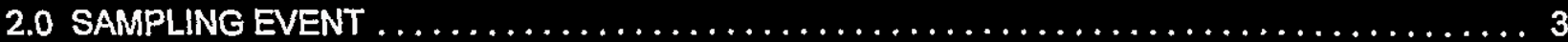

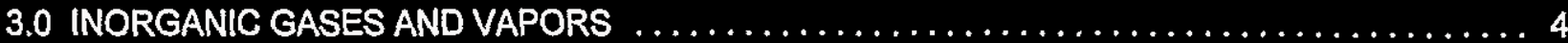

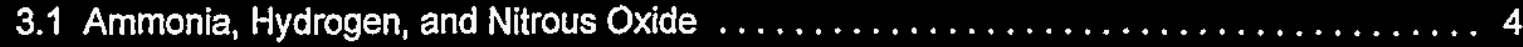

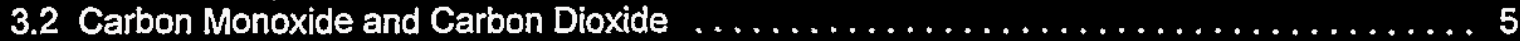

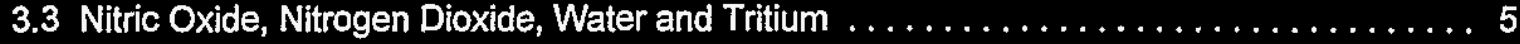

3.4 Discussion of Inorganic Gases and Vapors $\ldots \ldots \ldots \ldots \ldots \ldots \ldots \ldots \ldots \ldots$

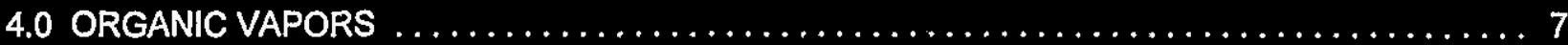

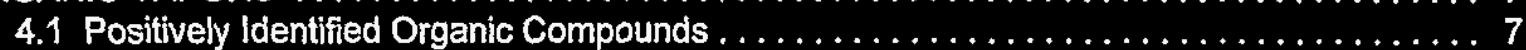

4.2 Tentatively Identified Organic Compounds $\ldots \ldots \ldots \ldots \ldots \ldots \ldots \ldots \ldots \ldots$

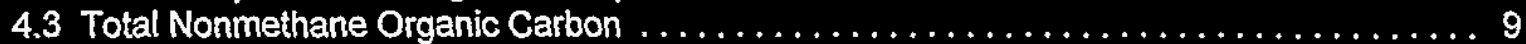

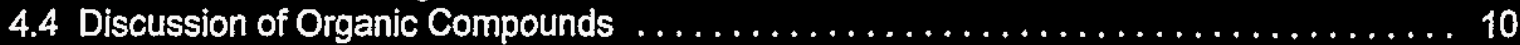

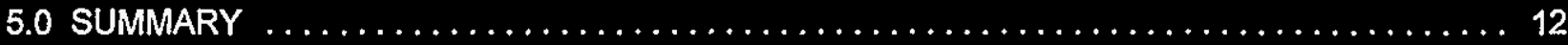

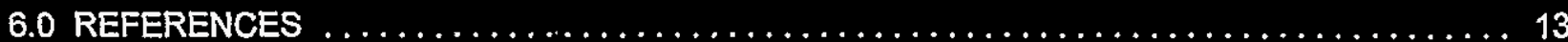

\section{Acronyms and Abbreviations}

CES

EPA

GC

GC/MS

LFL

MS

NFPA

NPH

OGIST

ORNL.

PNL

ppmv

TNMOC

TST

vol\%

VSS

WHC consensus exposure standard

Environmental Protection Agency

gas chromatograph

gas chromatograph/mass spectrometer

lower flammability limit

mass spectrometer

National Fire Protection Association

normal paraffinic hydrocarbon

Oregon Graduate Institute of Science and Technology

Oak Ridge National Laboratory

Pacific Northwest Laboratory

parts per million by volume, $1 \mathrm{ppmv}=10^{-4} \mathrm{vol} \%$

total nonmethane organic carbon

triple sorbent trap

percent by volume, $1 \mathrm{vol} \%=10,000 \mathrm{ppmv}$

vapor sampling system

Westinghouse Hanford Company 
WHC-SD-WM-ER-445 Rev. 1

\section{Acknowledgements}

The authors wish to thank Chris Simonen for her work verifying data and generating tables, and Shas Mattigod for his help with the construction and reviews of this document. The authors also wish to thank Luther Buckley, Clarence Homi, and Tom Kunthara for their contributions to the final reviews and publication of this document. 
WHC-SD-WM-ER-445 ReV. 1

Tank 241-C-107 Headspace Gas and Vapor Characterization Results

for Samples Collected in September 1994

\subsection{INTRODUCTION}

\subsection{Characterization Objectives}

Tank C-107 headspace gas and vapor samples were collected and analyzed to help determine the potential risks to tank farm workers due to fugitive emissions from the tank. The drivers and objectives of waste tank headspace sampling and analysis are discussed in Program Plan for the Resolution of Tank Vapor Issues (Osborne and Huckaby 1994). Tank C-107 was vapor sampled in accordance with Data Quality Objectives for Generic In-Tank Health and Safety /ssue Resolution (Osborne et al. 1994).

\subsection{Characterization Data Criteria}

Data Quality Objectives for Generic in-Tank Health and Safety issue Resolution describes parameters for data collection to ensure appropriate conclusions can be drawn from the data. Tank headspace characterization data was collected to help in the evaluation of 1) headspace flammability, and 2) identification and quantification of compounds of toxicological concern.

Single Shell Tank Interim Operational Safety Requirements (Dougherty 1995) specifies that combustible constituents in tank headspaces be maintained below $25 \%$ of the lower flammability limit (LFL). This essentially agrees with National Fire Protection Association requirements that combustible concentrations be maintained at or below $25 \%$ of the LFL (NFPA 1992). However, current governing operating specifications for single shell waste tanks, such as tank C-107, specify that combustible constituents be maintained at or below $20 \%$ of the LFL (Boyles 1994).

Headspace characterization data are used by Westinghouse Hanford Company (WHC) Tank Waste Remediation Systems Industrial Hygiene as source term data in the industrial hygiene strategy to protect workers from tank fugitive emissions. Because selection of worker protective equipment must be based on industrial hygiene monitoring of the work place and not on source term data (29 CFR 1910.120), tank headspace characterization data can not be used for this purpose. Furthermore, because there are mechanisms by which headspace constituents can be either diluted or concentrated as they are released to the atmosphere, the headspace characterization data should not be considered to be representative of emissions at the point of emission.

These statements notwithstanding, the data quality objectives document specifies that the industrial hygiene group be advised if constituents with toxicological properties exceed $50 \%$ of the appropriate consensus exposure standard (CES) for non-carcinogens, or $10 \%$ of the appropriate CES for carcinogens. A CES is defined as the most stringent of known regulatory or recommended toxicological values for the workplace (Osborne et al. 1994). 


\subsection{Sampling Overview}

Tank C-107 was vapor sampled in June 1994 using the in situ sampling (ISS) method, and again in September 1994 using the more robust vapor sampling system (VSS) method. Unfortunately, the ISS event sorbent trap samples were radiologically contaminated, and were never anaiyzed (Huckaby and Babad 1995). Furthermore, there are discrepancies between results from the ISS and VSS methods that are not understood (Huckaby 1994a), and until the ISS method has been validated and the discrepancies resolved, results from early iSS events should be considered suspect. Results presented here are all from the September 1994 VSS sampling event. Pingel (1994) provides field sampling information for the tank C-107 June 1994 ISS event, and MicVeety et al. (1995a) provide sample analysis results.

\subsection{Tank Headspace Dynamics}

Tank C-107 is the first tank in a 3-tank cascade with tanks C-108 and C-109. It is connected to tank C108 via a 7.4-cm (2.9-in.) inside diameter, 7.6-m (25-ft) long underground cascade line. Tanks C-108 and C-109 are connected by a similar line. Since these cascade lines connect the headspaces of these tanks, gases and vapors originating from the wastes in tanks C-108 or C-109 may be transferred to tank C-107 (unless the cascade lines are obstructed). However, headspace data, as discussed in Section 3.4, indicate that the inter-tank exchange of gases and vapors has little effect on the headspace composition of tank C-107.

The cascade of tanks $\mathrm{C}-107, \mathrm{C}-108$, and $\mathrm{C}-109$ is passively ventilated, which means that the tanks are allowed to exhale air, waste gases, and vapors as the barometric pressure falls, and inhale ambient air as the barometric pressure rises. Each of these tanks has its own filtered breather riser. Barometric pressure typically rises and falls on a diurnal cycle, producing an average daily exchange of air equal to about $0.46 \%$ of each tank headspace (Huckaby 1994b). Changes in the concentrations of tank headspace constituents due to barometric pressure changes are consequently very slow. 


\subsection{SAMPLING EVENT}

Headspace gas and vapor samples were collected from tank C-107 using the VSS on September 29, 1994 by WHC Sampling and Mobile Laboratories (WHC 1995). Sample collection and analysis were performed as directed by the sample and analysis plan' (WHC 1995, Appendix A). The tank headspace temperature was determined to be $45.9^{\circ} \mathrm{C}$. Air from the $\mathrm{C}-107$ headspace was withdrawn from a single elevation via a 7.9-m long heated sampling probe mounted in riser 8 , and transferred via heated tubing to the VSS sampling manifold. All heated zones of the VSS were maintained at approximately $50^{\circ} \mathrm{C}$. All tank air samples were collected between 7:22 a.m. and 10:45 a.m., with no anomalies noted.

Sampling media were prepared and analyzed by WHC, Oak Ridge National Laboratories (ORNL), Pacific Northwest Laboratories (PNL), and Oregon Graduate institute of Science and Technology (OGIST) through a contract with Sandia National Laboratories. The 39 tank air samples and 2 ambient air control samples collected are listed in Table 2-1 by analytical laboratory. Table 2-1 also lists the 14 trip blanks and 2 field blanks provided by the laboratories.

A general description of vapor sampling and sample analysis methods is given by Huckaby and Babad (1995). The sampling equipment, sample collection sequence, sorbent trap sample air flow rates and flow times, chain of custody information, and a discussion of the sampling event itself are given in WHC (1995).

1 The current requirement that sampling and analysis parameters be specified by a tank characterization plan was not in effect for gas and vapor sampling until October $1,1994$. 


\subsection{INORGANIC GASES AND VAPORS}

Analytical results of sorbent trap and SUMMA ${ }^{T M, 2}$ canister tank air samples for selected inorganic gases and vapors are given in Table 3-1 in parts per million by volume (ppmv) in dry air. The concentration of water vapor given in Table 3-1 has been adjusted to tank conditions as given in Section 3.3. Inorganic analyte sorbent traps were prepared and analyzed by PNL. SUMMA ${ }^{\mathrm{TM}}$ canisters were prepared and analyzed for inorganic analytes by both PNL and OGIST. Reports by Pool et al. (1995) and Rasmussen (1994) describe sample preparation and analyses.

PNL analyses of SUMMA ${ }^{\mathrm{TM}}$ canisters and sorbent traps for inorganic compounds were performed 99 and 14 days, respectively, after sample collection (Ligotke 1995). It should be noted that the inorganic compounds from SUMMA ${ }^{\mathrm{TM}}$ canister analyses (i.e., the permanent gases) would be expected to be very stable in the SUMMA ${ }^{T M}$ canisters, and the results may not have been affected even though the 60-day holding time requirement (Keller 1994) were exceeded. The 60-day holding time was administratively chosen, and no holding time study has been performed to address the stability of compounds in SUMMA ${ }^{\text {TM }}$ canisters in the chemical matrix of the waste tank samples.

PNL results were produced at PNL quality assurance impact level 3. OGIST did not have a WHCapproved quality assurance project plan in place when performing analyses, so OGIST data have been placed in square brackets both in Table 3-1 and elsewhere in this report to indicate that they represent secondary results.

\subsection{Ammonia, Hydrogen, and Nitrous Oxide}

Ammonia concentration in headspace of tank C-107 was reported as 84 ppmv. Ammonia has been observed in virtually all of the waste tanks sampled to date, at concentrations ranging from about $3 \mathrm{ppmv}$ in tank C-108 (Lucke et al. 1995), to 1040 ppmv in BY-108 (McVeety et al. 1995b). Given the LFL of ammonia in air is about $15 \%$ by volume (vol\%), the measured 84 ppmv corresponds to about $0.06 \%$ of the LFL, and does not contribute appreciably to the flammability of the headspace.

The concentration of hydrogen in tank C-107 was determined to be [230 ppmv] in SUMMA ${ }^{\mathrm{TM}}$ canisters by OGIST, and < 80 ppmv in SUMMA ${ }^{\mathrm{TM}}$ canisters by PNL. Hydrogen in the waste tanks is of concern as a fuel. Given that the LFL for hydrogen in air is about 4 vol\%, the higher measurement, [ $230 \mathrm{ppmv}$ ], would correspond to about $0.6 \%$ of its LFL. At this level, hydrogen is not a flammability concern in tank C-107.

The nitrous oxide concentration in tank C-107 was determined to be [78 ppmv] by OGIST and 41 ppmv by PNL. Nitrous oxide has been detected in other passively ventilated waste tanks at concentrations as low as about 12 ppmv in tank TX-105 (Klinger et al. 1995), and as high as about 878 ppmv in tank U-103 (Ligotke et al. 1995). Under the proper conditions, nitrous oxide can serve as an oxidizer to support combustion. However, Cashdollar et al. (1992) found that nitrous oxide had no significant effect on the flammability of hydrogen and air mixtures for hydrogen concentrations less than $20 \mathrm{vol} \%$, and that "small amounts of nitrous oxide (relative to air) do not appear to have much effect on the flammability". Their results suggest the measured nitrous oxide concentration is much too low to have a significant effect on the flammability of the tank C-107 headspace.

2 SUMMA is a trademark of Molectrics, Inc., Cleveland, Ohio. 


\subsection{Carbon Monoxide and Carbon Dioxide}

Carbon monoxide in the tank C-107 headspace samples was measured to be [1.7 ppmv] by OGIST, and as < 20 by PNL. At [1.7 ppmv], carbon monoxide would be much higher than it is in ambient air, where it typically ranges from 0.05 to 0.15 ppmv. Elevated waste tank headspace carbon monoxide concentrations are common, and are thought to be due to the decomposition of organic waste in the tanks. Carbon monoxide has not been measured at very high levels in any of the waste tanks, the highest level measured to date was [26.7 ppmv] in tank C-103 (Huckaby and Story 1994).

The average carbon dioxide concentration in the tank C-107 headspace measured by OGIST to be [725 ppmv], and by PNL to be 654 ppmv. Both of these measurements indicate the carbon dioxide concentration in tank $\mathrm{C}-107$ is higher than it is in ambient air. Carbon dioxide is normally present in the ambient air at a concentration of 350 to 400 ppmv, and is typically lower than ambient in the waste tank headspaces. Carbon dioxide introduced by air exchange with the atmosphere is readily absorbed by caustic supernatant and interstitial liquids of the waste tanks, and converted to carbonate in solution. Carbon dioxide concentrations in tanks C-108 and C-109, given in Table 3-2, indicate that the source of carbon dioxide is within tank C-107. The apparent explanation of the above-ambient carbon dioxide concentration in tank $\mathrm{C}-107$ is that the aqueous supernate in this tank has a higher than typical carbonate ion concentration. Hall (1995) discusses the similar finding of high carbon dioxide concentration found in tank C-101.

\subsection{Nitric Oxide, Nitrogen Dioxide, Water and Tritium}

Nitric oxide and nitrogen dioxide concentrations in the tank C-107 headspace were determined to be 0.20 ppmv and $\leq 0.02 \mathrm{ppmv}$, respectively. These are both acid gases that would have very low equilibrium concentrations above the high pH sludge in tank C-107. The measurable presence of nitric oxide may be due to its formation from oxygen and nitrogen in the radiation field of the headspace. These constituents could potentially serve as oxidizers to support combustion, but at the measured concentrations would have a negligible effect on the flammability of the tank C-107 headspace.

The water vapor concentration of tank $\mathrm{C}-107$ was determined to be about $58.8 \mathrm{mg} / \mathrm{L}$, at the measured tank headspace temperature of $45.9^{\circ} \mathrm{C}$ and pressure of $984 \mathrm{mbar}$ (737.7 torr), (WHC 1995). This corresponds to a water vapor partial pressure of $86.4 \mathrm{mbar}\left(64.8\right.$ torr), to a dew point of $43.0^{\circ} \mathrm{C}$, and to a relative humidity of $86 \%$. The relative humidity in tank C-107 is similar to that in other 241-C farm tanks that contain primarily sludge waste.

Silica gel sorbent traps were used to sample for tritium. It is assumed that tritium produced by the waste combines with hydroxide ions to form tritium-substituted water. Evaporation of the tritium-substituted water would then result in airborne radioactive contamination. Silica gel sorbent traps adsorb virtually all (normal and tritium-substituted) water vapor from the sampled tank air, and are analyzed at the WHC 222$S$ laboratory. Radiochemical analysis of the silica gel trap indicated the total activity of the headspace to be less than $50 \mathrm{pCi} / \mathrm{L}$ (WHC 1995).

\footnotetext{
3 The carbon monoxide measurement in tank $\mathrm{C}-103$ was made by Oregon Graduate Institute of Science and Technology, and placed in brackets to emphasize it should be considered secondary data.
} 
WHC-SD-WM-ER-445 Rev. 1

\subsection{Discussion of Inorganic Gases and Vapors}

Aside from water and carbon dioxide, the most abundant waste constituents in the tank C-107 headspace are ammonia, hydrogen, and nitrous oxide. These have been detected in most tank headspaces sampled to date, and are usually the dominate waste species. For comparison and perspective, Table 3-2 presents selected inorganic gas and vapor concentrations for tanks C-107, C-108, and C-109.

Differences between OGIST and PNL results for carbon dioxide, hydrogen, and nitrous oxide are apparently due to analytical error. Collection of all SUMMA ${ }^{\mathrm{TM}}$ samples occurred within a 35 minute period, and sampling errors are not a probable cause for the reported discrepancies.

The relative standard deviations of the inorganic gas and vapor results given in the last column in Table 31 are very good. Relative standard deviations range from less than $1 \%$ for the OGIST measurement of carbon dioxide and nitrous oxide, to $17 \%$ for PNL carbon dioxide results. Because the precision reported depends both on sampling parameters (e.g., sample flow rate and flow time) and analytical parameters (e.g., sample preparation, dilutions, etc.) for the sorbent trap samples, the small relative standard deviations for these results suggest proper control was maintained both in the field and in the laboratories.

As discussed in Section 1.4, the headspaces of tanks C-107 and C-108 are connected by an underground cascade line. Similarly, the headspaces of tanks C-108 and C-109 are connected by a cascade line. To examine the possibility that constituents of the tank C-107 headspace are actually generated in tank C108 or C-109 and introduced to tank C-107 via the cascade line, the inorganic gas and vapor results from the headspace characterization of tanks C-107, C-108, and C-109 are given in Table 3-2. From Table 3-2 it can be concluded (assuming all results presented are valid) that the primary source of ammonia, hydrogen, carbon dioxide, carbon monoxide, and water vapor in the tank C-107 headspace is the waste in tank C-107. 


\section{WHC-SD-WM-ER-445 Rev. 1}

\subsection{ORGANIC VAPORS}

Organic vapors in the tank C-107 headspace were sampled using SUMMATM canisters, which were analyzed by OGIST and PNL, and triple sorbent traps (TSTs), which were analyzed by ORNL. PNL and ORNL both used a gas chromatograph (GC) equipped with a mass spectrometer (MS) detector to separate, identify, and quantitate the analytes. Methane and total nonmethane organic carbon (TNMOC) concentrations were measured by OGIST using GCs with flame ionization detectors. Descriptions of sample device cleaning, sample preparations, and analyses are given by Jenkins et al. (1994), Rasmussen (1994), and Pool et al. (1995).

SUMMA ${ }^{T M}$ sample results should be considered to be the primary organic vapor data for tank C-107. PNL results were produced at PNL quality assurance impact level 3. All PNL organic vapor analyses were completed 103 days after sample collection, which exceeds the administratively chosen 60-day holding time (Keller 1994). No holding time study has been performed to determine the stability of analytes in SUMMA ${ }^{\text {TM }}$ canisters in the chemical matrix of the tank samples.

ORNL analyses of TST samples from this and other waste tanks generally agree with, support, and augment the SUMMA ${ }^{\mathrm{TM}}$ sample results. However, because certain WHC quality assurance requirements were not satisfied by ORNL, the quality assurance assessment of ORNL by Hendrickson (1995) should be reviewed before results unique to the TST samples are used for decision making.

All TSTs prepared by ORNL had 3 surrogate compounds added to evaluate sample matrix effects, potential handling, storage, and shipment problems, and analytical instrumentation performance (Jenkins et al. 1994). ORNL evaluated the surrogate recoveries using a statistical approach similar to that prescribed by SW 846 Method 8260 A Volatile Organic Compounds by Gas Chromatography/Mass Spectrometry (GC/MS) Capillary Column Technique (EPA 1992). Using this approach, ORNL reported that surrogates had standard deviation values outside the $95 \%$ confidence interval for variance, suggesting that a bias may have been introduced in the measurement of analyte quantities (Jenkins 1995a).

\subsection{Positively Identified Organic Compounds}

Positive identification of organic analytes using the methods employed by PNL. and ORNL involves matching the GC retention times and MS data from a sample with that obtained when known compounds were analyzed. The concentration of an analyte in the sample is said to be quantitatively measured if the response of the GC/MS has been established at several known concentrations of that analyte (i.e., the GC/MS has been calibrated for that analyte), and the MS response to the analyte in the sample is between the lowest and highest responses to the known concentrations (i.e., the analyte is within the calibration range).

ORNL and PNL were assigned different lists of organic compounds, or target analytes, to positively identify and measure quantitatively. The ORNL target analyte list was derived from a review of the tank C103 headspace constituents by a panel of toxicology experts (Mahlum et al. 1994). The PNL target analyte list included the 40 compounds in the Environmental Protection Agency (EPA) task order 14 (TO14) method, which are primarily halocarbons and common industrial solvents (EPA 1988), plus 15 analytes selected from the toxicology panel's review of tank C-103.

Table 4-1 lists the organic compounds positively identified and quantitated in SUMMA ${ }^{\mathrm{TM}}$ samples. Analysis for methane was performed by OGIST (Rasmussen 1994), other SUMMA ${ }^{\text {TM }}$ analyses were 
performed according to the TO-14 methodology by PNL (EPA 1988, Pool et al. 1995). None of the 40 TO14 target analytes and only 3 of the 15 additional target analytes were measured to be above the 0.005 ppmv detection limit of the analyses. Averages reported are from analyses of 3 SUMMA ${ }^{\mathrm{TM}}$ canister samples.

Jenkins et al. (1994) report the positive identification of 25 of 27 target analytes in TST samples. 1,1Dichloroethene and dibutyl butylphosphonate were the only TST target analytes not detected in the TST samples. Tributyl phosphate was positively identified, but its concentration was too low to be quantitatively measured. Despite calibration of the instrument over about a 20-fold concentration range, 18 of the positively identified compounds were measured to be outside of the calibration range in at least 1 of the 3 TST samples. The average concentrations of the positively identified compounds are given in Tables 4-2, 4-3, and 4-4. Table 4-2 lists the positively identified, quantitated analytes, Table 4-3 lists the positively identified analytes which were not quantitated (because the measurement was outside the calibration range for at least 1 sample), and Table 4-3 lists the positively identified analytes which exceeded their practical holding times. Tables 4-2, 4-3, and 4-4 are mutually exclusive, so that no analyte appears in more than 1 of these tables. Data in Tables 4-3 and 4-4 should not be considered quantitative and may not be accurate to within $₫ 30 \%$ as specified by Burnum (1995).

The ORNL practical holding time is defined as the holding time for which there is a $15 \%$ risk that the concentration of an analyte in the sample will be below its initial concentration. As indicated in Table 4-4, butanal and 1-butanol exceeded their practical holding times, and may have been affected by the 25 day period between sample collection and analysis (Jenkins 1995b). Jenkins et al. (1995) describe the ORNL. practical holding time study, and report the practical holding times of butanal, 1 -butanol, and 2-pentanone are 1,17 , and 34 days, respectively. It should be noted that the contractual holding time for the TST samples was 60 days.

Eleven target analytes were common to both TST and SUMMA ${ }^{\text {TM }}$ analyses. Table 4-5 lists these, and their reported average concentrations in TST and SUMMA ${ }^{\text {TM }}$ samples. The reported TST sample concentrations of 1,1-dichloroethene and nonpolar compounds (i.e., benzene, toluene, n-hexane, nheptane, and n-decane) in Table 4-3 are all $<0.003$ ppmv, and below the SUMMA ${ }^{\mathrm{TM}}$ analysis method detection limit.

The propanone concentration in the SUMMA ${ }^{\mathrm{TM}}$ samples was reported to be 8.8 times as high as in TST samples. Differences between the TST and SUMMA ${ }^{\text {TM }}$ results for dichloromethane were significant, but may be due to problems with the TST preparation, handling, or analysis. Specifically, the reported dichloromethane results from the 3 TST samples are very inconsistent, being $0.0096,<0.0011$, and 0.41 ppmv.

There is also disagreement regarding nitrile concentrations in SUMMA ${ }^{\mathrm{TM}}$ and TST samples from tank C107. Ethanenitrile was measured in SUMMA ${ }^{T M}$ samples to be 0.64 ppmv, and oniy 0.25 ppmv in TST samples. Also, as shown in Table 4-5, the average concentrations of propanenitrile, and n-butanenitrile in TST samples were well above the 0.005 ppmv SUMMA ${ }^{\mathrm{TM}}$ method detection limit, yet these analytes were not found in the SUMMA ${ }^{\mathrm{TM}}$ samples. In lieu of reasons to discount either sampling and analysis method, the higher results should be used as the best measurement of these nitriles.

The most abundant anaiytes in Tables 4-1 through 4-4 are methane, propanone, n-dodecane, ethanenitrile, n-tridecane, 1-butanol, and n-undecane. At the reported concentrations, the target analytes do not individually or collectively represent a flammability hazard. 
WHC-SD-WM-ER-445 Rev. 1

\subsection{Tentatively Identified Organic Compounds}

In addition to the target analytes, the ORNL and PNL analytical procedures allow the tentative identification of other organic compounds. Tentative identification of analytes was performed by comparing the MS molecular fragmentation patterns with a library of known MS fragmentation patterns. This method allows an organic analyte to be identified (with reasonable certainty) as an alkane, a ketone, an aldehyde, etc., and may also determine its molecular weight. The method usually does not, however, allow the unambiguous identification of structural isomers, and this ambiguity increases with analyte molecular weight. Using this method, many analytes can be tentatively identified with reasonable confidence without having to inject each into the GC/MS to determine their GC retention times or specific MS patterns.

By the nature of the sampling devices, virtually all organic vapors present in the tank headspace are collected by both TST and SUMMA ${ }^{\text {M }}$ samples. Analyses of the samples are designed to recover, separate, and identify the organic vapors in the samples. TSTs are not good for collecting highly volatile compounds (i.e., molecules more volatile than propane), but are quite good for most others. In contrast, the recovery of very low volatility compounds (e.g., molecules with more than about 15 carbon atoms) and some polar compounds with moderate volatility (e.g., butanal) from SUMMA ${ }^{\text {TM }}$ samples has been problematic.

The list of tentatively identified compounds recovered from SUMMA ${ }^{\mathrm{TM}}$ samples, with estimated concentrations, is given in Table 4-6. Compounds are listed in Table 4-6 in the order by which they eluted chromatographically, and only non-zero results are included in the reported averages. The tentatively identified compounds detected in TST samples, and their estimated concentrations, are listed in Table 4-7. Compounds are listed in Table 4-7 according to the order by which the eluted chromatographicaliy. The averages reported by ORNL in Table 4-7 are all 3-sample averages, and if an analyte was not detected in a sample, its concentration in that sample was considered to be zero for averaging purposes. Estimated concentrations are in $\mathrm{mg} / \mathrm{m}^{3}$, based on dry air at $0^{\circ} \mathrm{C}$ and 1.01 bar.

Because the list of tentatively identified organic compounds in TST samples is particulariy long and locating any given compound may be difficult, the list has been sorted alphanumerically by compound name in Table 4-8. Table 4-9 gives the same list, sorted in order of decreasing estimated concentration. Numbers in the first columns of Tables 4-8 and 4-9 (Cmpd \#) identify the location of the compound in Table 4-7.

The ORNL and PNL methods used to tentatively identify and estimate concentrations are described by Jenkins et al. (1994) and Pool et al. (1995), respectively, and should be reviewed before this data is used for decision making. Concentrations given in Tables 4-6 through 4-9 should be considered rough estimates. Results in these tables are presented in terms of observed peaks, and are not adjusted for the occurrence of split chromatographic peaks (e.g., Cmpd \# 13 and 14 in Table 4-7) or the assignment of the same identity to different peaks (e.g., Cmpd \# 120, 131, 138, and 141 in Table 4-7). In these instances, the estimated concentration of a compound appearing as a doublet or triplet is simply the sum of the individual peak estimates.

\subsection{Total Nonmethane Organic Carbon}

OGIST measured the TNMOC concentration in 3 SUMMA ${ }^{T M}$ canister samples using the U.S.

Environmental Protection Agency (EPA) task order 12 (TO-12) method (Rasmussen 1994, EPA 1988). The sample mean was $\left[3.6 \mathrm{mg} / \mathrm{m}^{3}\right]$, with a standard deviation of $\left[0.1 \mathrm{mg} / \mathrm{m}^{33}\right.$. This value is relatively low 
compared to other waste tanks sampled to date. The sum of quantitatively measured and estimated TST organic analyte concentrations, by GC/MS analyses, is $3.7 \mathrm{mg} / \mathrm{m}^{3}$ (Jenkins et al. 1994). This is in excellent agreement with the EPA TO-12 result.

\subsection{Discussion of Organic Compounds}

A convenient way to consider the organic compounds listed in Tables 4-1 through 4-7 is to separate them into 2 categories: 1) Organic compounds added to tank C-107 as waste that are still evaporating; and 2) organic compounds that have been generated by reactions of the original waste.

Organic vapors in the first category, those that were placed into the tank as waste, include tributyl phosphate and the semivolatile straight-chain alkanes, which were used as diluents of tributyl phosphate in various plutonium extraction processes. These alkanes (i.e., n-undecane, n-dodecane, n-tridecane, ntetradecane, and $n$-pentadecane) are often referred to in Hanford site literature as the normal parafinic hydrocarbons (NPHs).

The tentatively identified cyclosiloxanes (i.e., Cmpd \# 25 and 46 in Table 4-7) may also be in this category. Small quantities of siloxanes may have been introduced to the waste tank through their use as process surfactants, but they may also be present in the headspace due to their use in liquid traps at the tank's breather riser.

Decahydronaphthalene and methyl-substituted decahydronaphthalenes have been tentatively identified in many of the NPH-rich waste tanks, but were not found in tank C-107. This may be an indication that the organic waste in tank $\mathrm{C}-107$ originated when the plutonium extraction process were using a relatively pure NPH diluent.

The second category includes all organic compounds that have been generated via radiolytic and chemical reactions of the waste. The majority of compounds listed in Tables 4-1 through 4-9 fall into this category. The alcohols, aldehydes, ketones, nitriles, alkenes, alkyl nitrates, and volatile alkanes, are all thought be degradation products of the NPHs. The hydrolysis of tributyl phosphate, for example, is thought to be the principal source of 1-butanol. By far the most abundant of these degradation products in the headspace are the short-chain volatile compounds, however, Table 4-7 lists many long-chain low volatility compounds that are also probably waste reaction products.

Samples from tank C-107 were found to have several alkyl nitrates and organic acids. Though it is reasonable to expect alkyl nitrates and organic acids to be produced via chemical and radiolytic processes of the NPH with other waste, their solubility in the aqueous waste supernates would also be expected to significantly reduce their vapor-phase concentrations. That these constituents are at detectible levels in tank C-107 may indicate dry conditions where they are formed.

Selected organic vapor concentrations in tanks C-107, C-108, and C-109 are given in Table 3-2 for comparison. Because the listed organic vapors are at higher concentrations in tank C-107 than in tank C108 , it can be concluded that their presence in the tank C-107 headspace is due principally to their presence in the waste of that tank.

In summary, the organic vapor concentrations in tank C-107 are relatively low. While not completely typical of NPH-rich tanks, the organic vapors in tank C-107 clearly indicate the presence of trace amounts of the semivolatile NPHs and their degradation products. Consideration of data given in Table 3-2 and the cascade line between the headspaces of tanks C-107 and C-108 suggests that most organic vapors in the 
WHC-SD-WM-ER-445 Rev. 1

headspace of tank $\mathrm{C}-107$ are generated by evaporation or chemical reaction within tank C-107, and are not from tank C-108. 


\subsection{SUMMARY}

The tank C-107 headspace was sampled in September 1994 for gases and vapors to address flammability and industrial hygiene concerns. Results unique to the sampling event and essentially all results have been reported. It was determined that no headspace constituents exceeded the flammability notification limits specified in the current Vapor Sampling and Analysis Plan (Homi 1995). 
WHC-SD-WM-ER-445 Rev. 1

\subsection{REFERENCES}

29 CFR 1910.120, 1993, "Hazardous Waste Operations and Emergency Response", Code of Federal Regulations.

Boyles, V. C., 1994, Operating Specifications for Single Shell Waste Storage Tanks, OSD-T-151-00013 Rev. D-4, Westinghouse Hanford Company, Richland, Washington.

Burnum, S. T., 1995, Qualification of Reported WHC Vapor Program Data, (letter 95-CHD-065 to president, Westinghouse Hanford Company, August 18), Department of Energy, Richland Operations Office, Richland, Washington.

Cashdoller, K. L., M. Hertzberg, I. A. Zlochower, C. E. Lucci, G. M. Green, and R. A. Thomas, 1992, Laboratory Flammability Studies of Mixtures of Hydrogen, Nitrous Oxide, and Air, WHC-SD-WMES-219 Rev. 0, Westinghouse Hanford Company, Richland, Washington.

Dougherty, L. F., 1995, Single Shell Tank Interim Operational Safety Requirements, WHC-SD-WM-OSR005 Rev. 0, Westinghouse Hanford Company, Richland, Washington.

EPA 1988, Compendium of Methods for the Determination of Toxic Organic Compounds in Ambient Air, PB90-127374, U.S. Environmental Protection Agency, Washington, D.C.

EPA 1992, Test Methods for Evaluating Solid Waste, SW-846 Rev. 1, U.S. Environmental Protection Agency, Washington, D.C.

Hall, B.W., 1995, Tank Characterization Report for Single-Shell Tank 241-C-101, Rev.0, Westinghouse Hanford Company, Richland, Washington.

Hendrickson, R. W., 1995, Tank Vapor Characterization Oak Ridge National Laboratories Quality Assurance Assessment, TWRSQA-95-0012, Westinghouse Hanford Company, Richland, Washington.

Homi, C. S., 1995, Vapor Sampling and Analysis Plan, WHC-SD-WM-TP-335 Rev. 0G, Westinghouse Hanford Company, Richland, Washington.

Huckaby, J. L., 1994a, Vapor Sampling System (VSS) and In Situ Sampling (ISS) Method Comparison, WHC-SD-WM-RPT-101 Rev. 0, Westinghouse Hanford Company, Richland, Washington.

Huckaby, J. L., 1994b, Tank 241-C-103 Headspace Flammability, WHC-EP-0734 Rev. 1, Westinghouse Hanford Company, Richland, Washington.

Huckaby, J. L., 1995a, Tank 241-C-108 Headspace Gas and Vapor Characterization Results for Samples Collected in July 1993 and August 1994, WHC-SD-WM-ER-423 Rev. 2, Westinghouse Hanford Company, Richland, Washington.

Huckaby, J. L., 1995b, Tank 241-C-109 Headspace Headspace Gas and Vapor Characterization Results for Samples Collected in August 1994, WHC-SD-WM-ER-424 Rev. 2, Westinghouse Hanford Company, Richland, Washington. 
WHC-SD-WM-ER-445 Rev. 1

Huckaby, J. L., and M. S. Story, 1994, Vapor Characterization of Tank 241-C-103, WHC-EP-0780 Rev. 0, Westinghouse Hanford Company, Richland, Washington.

Huckaby, J. L., H. Babad, and D. R. Bratzel, 1995, Headspace Gas and Vapor Characterization Summary for the 43 Vapor Program Suspect Tanks, WHC-SD-WM-ER-514 Rev. 0, Westinghouse Hanford Company, Richland, Washington.

Jenkins, R. A., 1995a, Untitled, (Letter 090195A to D. Bratzel, September 1), Oak Ridge National Laboratory, Oak Ridge, Tenessee.

Jenkins, R.A., 1995b, Untitled, (Letter 091495A to D. Bratzel, September 14), Oak Ridge National Laboratory, Oak Ridge, Tenessee.

Jenkins, R. A, A. B. Dindal, C. E. Higgins, C. Y. Ma, M. A. Palausky, J. T. Skeen, and C. K. Bayne, 1994, Analysis of Tank 241-C-107 Headspace Components, ORNL-CASD-FR-241C107.95 Rev. 0, Oak Ridge National Laboratory, Oak Ridge, Tennessee.

Jenkins, R. A, A. B. Dindal, C. Y. Ma, M. A. Palausky, J. T. Skeen, and C. K. Bayne, 1995, Analysis of Tank 241-TY-104 Headspace Components, ORNL-CASD-FR-241TY104.95 Rev. 1, Oak Ridge National Laboratory, Oak Ridge, Tennessee.

Keller, K. K., 1994, Quality Assurance Project Plan for Tank Vapor Characterization, WHC-SD-WMQAPP-013 Rev. 2, Westinghouse Hanford Company, Richland, Washington.

Klinger, G. S., T. W. Clauss, M. W. Ligotke, K. H. Pool, R. B. Lucke, B. D. McVeety, O. P. Bredt, J. S. Young, M. McCulloch, J. S. Fruchter, and S. C. Goheen, 1995, Vapor Space Characterization of Waste Tank 241-TX-105: Results from Samples Collected Through the Vapor Sampling System on 12/20/94, PNL-10594 UC-606, Pacific Northwest Laboratory, Richland, Washington.

Ligotke, M. W. 1995, PNL Vapor Project Analytical Holding Times, (Letter to D. R. Bratzel, September 23), Pacific Northwest Laboratory, Richland, Washington.

Ligotke, M. W., K. H. Pool, T. W. Clauss, B. D. MoVeety, G. S. Klinger, K. B. Olsen, O. P. Bredt, J. S. Fruchter, and S. C. Goheen, 1995, Vapor Space Characterization of Waste Tank 241-U-103: Results from Samples Collected on 2/15/95, PNL-10813 UC-606, Pacific Northwest Laboratory, Richland, Washington.

Lucke, R. B., M. W. Ligotke, K. H. Pool, T. W. Clauss, A. K. Sharma, B. D. MoVeety, M. McCulloch, J. S. Fruchter, and S. C. Goheen, 1995, Vapor Space Characterization of Waste Tank 241-C-108: Results from Samples Collected Through the Vapor Sampling System on 8/5/94, PNL-10351 UC606, Pacific Northwest Laboratory, Richland, Washington.

Mahlum, D. D., J. Y. Young, and R. E. Weller, 1994, Toxicologic Evaluation of Analytes from Tank 231-C103, PNL-10189, Pacific Northwest Laboratory, Richland, Washington.

Meacham, J. E., H. Babad, R. J. Cash, G. T. Dukelow, S. J. Eberlein, D. W. Hamilton, G. D. Johnson, J. W. Osborne, M. A. Payne, D. J. Sherwood, D. A. Turner, and J. L. Huckaby, 1995, Approach for Tank Safety Characterization of Hanford Site Waste, WHC-EP-0843 Rev. 0, UC-2070, Westinghouse Hanford Company, Richland, Washington. 


\section{WHC-SD-WM-ER-445 Rèv. 1}

MoVeety, B. D., T. W. Clauss, M. W. Ligotke, K. H. Pool, R. B. Lucke, J. S. Young, M. McCulloch, J. S. Fruchter, and S. C. Goheen, 1995a, Vapor Space Characterization of Waste Tank 241-C-107 (In Situ): Results from Samples Collected on 6/17/94, PNL-10420 UC-606, Pacific Northwest Laboratory, Richland, Washington.

McVeety, B. D., T. W. Clauss, M. W. Ligotke, K. H. Pool, R. B. Lucke, G. S. Klinger, J. S. Young, M. McCulloch, J. S. Fruchter, and S. C. Goheen, 1995b, Vapor Space Characterization of Waste Tank 241-BY-108: Results from Samples Collected on 10/27/94, PNL-10495 UC-606, Pacific Northwest Laboratory, Richland, Washington.

NFPA 1992, Standard on Explosion Prevention Systems, NFPA 69, National Fire Protection Association, Quincy, Massachusetts.

Osborne, J. W., and J. L. Huckaby, 1994, Program Plan for the Resolution of Tank Vapor/ssues, WHCEP-0562 Rev. 1, Westinghouse Hanford Company, Richland, Washington.

Osborne, J. W., J. L. Huckaby, T. P. Rudolph, E. R. Hewitt, D. D. Mahlum, J. Y. Young, and C. M. Anderson, 1994, Data Quality Objectives for Generic In-Tank Health and Safety Issue Resolution, WHC-SD-WM-DQO-002, Westinghouse Hanford Company, Richland, Washington.

Pingel, L. A., 1994, Draft Report from the In-Situ Vapor Sampling of Waste Tank C-107, (Internal memorandum 8E920-SAS94-104, June 17), Westinghouse Hanford Company, Richland, Washington.

Pool, K. H., T. W. Clauss, M. W. Ligotke, R. B. Lucke, B. D. MoVeety, G. S. Klinger, J. S. Young, M. McCulloch, J. S. Fruchter, and S. C. Goheen, 1995, Vapor Space Characterization of Waste Tank 241-C-107: Results from Samples Collected on 9/29/94, PNL-10736 UC-606, Pacific Northwest Laboratory, Richland, Washington.

Rasmussen, R. A., 1994, Air Samples Collected at Waste Tank 241-C-107 on September 29, 1994 by Westinghouse Hanford in 6-L SS SUMMA® Canisters, Oregon Graduate Institute of Science and Technology, Beaverton, Oregon.

WHC 1995, Vapor and Gas Sampling of Single-Shell Tank 241-C-107 Using the Vapor Sampling System, WHC-SD-WM-RPT-129, Westinghouse Hanford Company, Richland, Washington. 



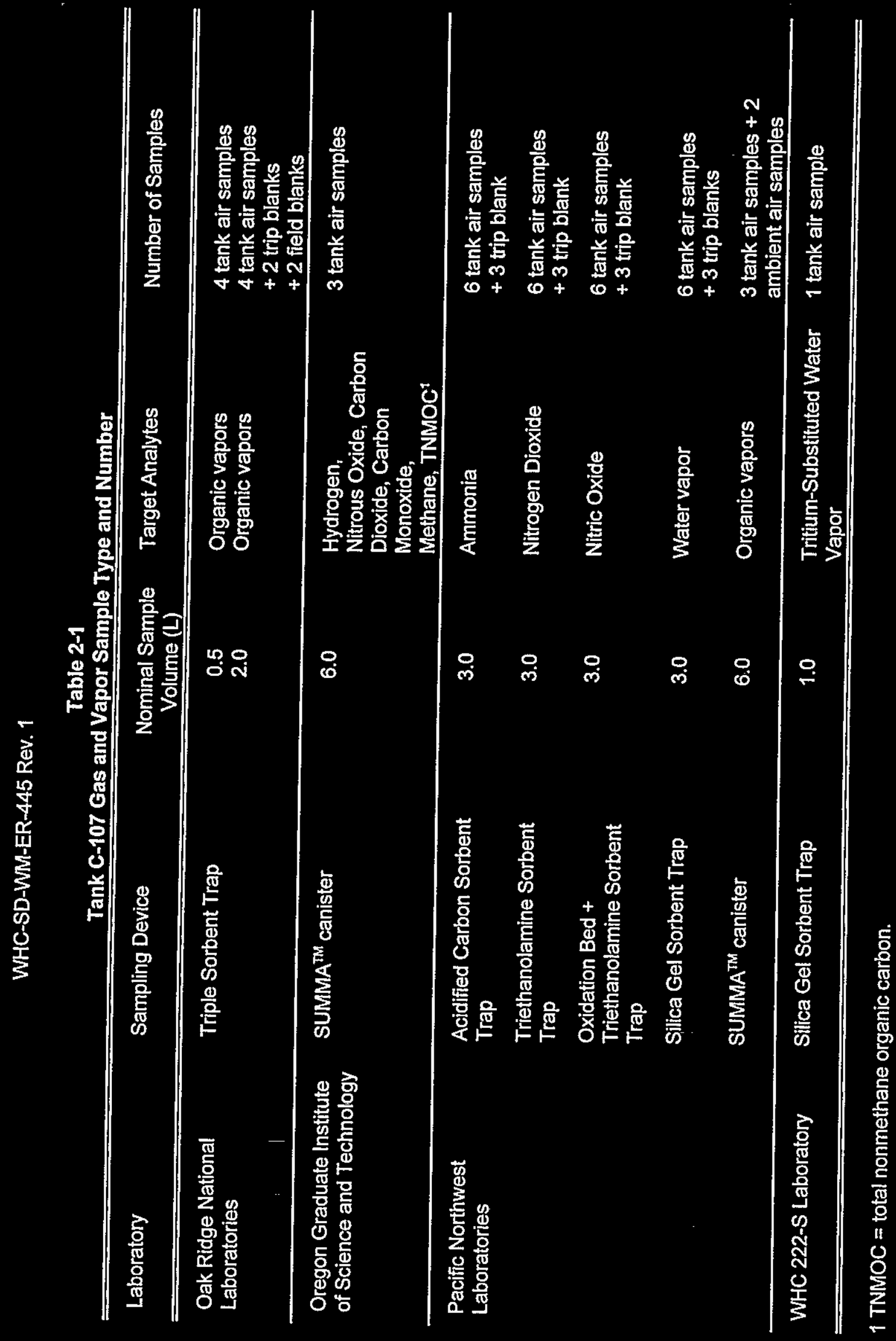


WHC-SD-WM-ER-445 Rev. 1

Table 3-1

Tank C-107 Inorganic Gas and Vapor Concentrations -Analyses by Oregon Graduate Institute of Science and Technology and by Pacific Northwest Laboratory

\begin{tabular}{|c|c|c|c|c|c|c|}
\hline Compound & $\begin{array}{c}\text { CAS }^{1} \\
\text { Number }\end{array}$ & $\begin{array}{l}\text { Sample } \\
\text { Type }\end{array}$ & $\begin{array}{c}\text { Number } \\
\text { of } \\
\text { samples }\end{array}$ & $\begin{array}{c}\text { Average }^{2} \\
\text { (ppmv) }\end{array}$ & $\begin{array}{c}\text { Standard } \\
\text { Deviation }^{2} \\
\text { (ppmv) }\end{array}$ & $\begin{array}{c}\mathrm{RSD}^{2.3} \\
(\%)\end{array}$ \\
\hline Ammonia, $\mathrm{NH}_{3}$ & $7664-41-7$ & Sorbent Trap & 6 & 84 & 2 & 2 \\
\hline Carbon dioxide, $\mathrm{CO}_{2}$ & $124-38-9$ & SUMMA ${ }^{T M}$ & 3 & $\begin{array}{r}654 \\
{[725]}\end{array}$ & $\begin{array}{l}112 \\
{[0.6]}\end{array}$ & $\begin{array}{l}17 \\
{[1]}\end{array}$ \\
\hline Carbon monoxide, CO & $630-08-0$ & SUMMA ${ }^{T M}$ & 3 & $\begin{aligned}< & 20 \\
& {[1.7] }\end{aligned}$ & $\overline{[0.05]}$ & $\overline{[3]}$ \\
\hline Hydrogen, $\mathrm{H}_{2}$ & $1333-74-0$ & SUMMA ${ }^{\text {TM }}$ & 3 & $\begin{array}{r}<80 \\
{[230]}\end{array}$ & [15] & $\ddot{[6]}$ \\
\hline Nitric oxide, NO & $10102-43-9$ & Sorbent Trap & 5 & 0.20 & 0.01 & - \\
\hline Nitrogen dioxide, $\mathrm{NO}_{2}$ & $10102-44-0$ & Sorbent Trap & 6 & $\leq 0.02$ & - & - \\
\hline Nitrous oxide, $\mathrm{N}_{2} \mathrm{O}$ & $10024-97-2$ & SUMMATM & 3 & $\begin{array}{r}41 \\
{[78]}\end{array}$ & $\begin{array}{c}6.4 \\
{[0.2]}\end{array}$ & $\begin{array}{l}16 \\
{[1]}\end{array}$ \\
\hline Water vapor, $\mathrm{H}_{2} \mathrm{O}$ & $7732-18-5$ & Sorbent Trap & 5 & $\begin{array}{l}87,800 \\
\quad(58.8 \mathrm{mg} / \mathrm{L})\end{array}$ & $\begin{array}{l}6,200 \\
(4.2 \mathrm{mg} / \mathrm{L})\end{array}$ & 7 \\
\hline
\end{tabular}

$1 \mathrm{CAS}=$ Chemical Abstracts Service.

2 Bracketed values are from OGIST and should be considered secondary results, non-bracketed values are from PNL and should be considered primary results.

3 RSD = relative standard deviation. Burnum (1995) specifies the RSD should be less than $25 \%$. 
Table 3-2

Comparison of Tank C-107, C-108, and C-109 Headspace Constituents -Inorganic Analyses by Pacific Northwest Laboratory and Oregon Graduate Institute of Science and Technology, and Organic Analyses by Oak Ridge National Laboratory ${ }^{4}$

\begin{tabular}{lccc}
\hline \hline Tank: & C-107 & C-108 & C-109 \\
\hline \hline Date sampled, (mo/day/yr) & $9 / 9 / 94$ & $8 / 5 / 94$ & $8 / 10 / 94$ \\
\hline Headspace temperature, $\left(^{\circ} \mathrm{C}\right)$ & 45.9 & 25 & 27 \\
\hline Ammonia, (ppmv) & 84 & 2.7 & 10.1 \\
Hydrogen, (ppmv) & {$[230]$} & {$[15.3]$} & {$[125]$} \\
Carbon dioxide, (ppmv) & {$[725]$} & {$[16.3]$} & {$[3]$} \\
Carbon monoxide, (ppmv) & {$[1.7]$} & {$[0.10]$} & {$[0.41]$} \\
Nitric oxide, (ppmv) & 0.20 & 0.24 & 0.51 \\
Nitrogen dioxide, (ppmv) & 50.02 & 50.04 & 5.06 \\
Nitrous oxide, (ppmv) & {$[78]$} & {$[344]$} & {$[369]$} \\
Water vapor, (mg/m ${ }^{3}$ ) & 70.7 & 17.5 & 20.4 \\
Water vapor, (\% relative humidity) & 86 & 76 & 79 \\
\hline Ethanenitrile (acetonitrile), (ppmv) & $(0.25)$ & $(0.0052)$ & $(0.26)$ \\
Propanone (acetone), (ppmv) & $(0.094)$ & 0.018 & $(0.012)$ \\
1-Butanol, (ppmv) & $(0.0025)$ & $(0.00049)$ & 0.0032 \\
n-Dodecane, (ppmv) & 0.0073 & $(0.00053)$ & $(0.00026)$ \\
n-Tridecane, (ppmv) & 0.0092 & $(0.0011)$ & $(0.00047)$ \\
\hline Total nonmethane organic compounds & {$[3.6]$} & {$[0.35]$} & {$[0.65]$} \\
by EPA TO-12 method, (mg/m ${ }^{3}$ ) & & & \\
\hline \hline
\end{tabular}

1 Where PNL inorganic gas or vapor data were unavailable for tanks C-108 and C-109, OGIST results are listed. OGIST results are given in brackets to indicate the data should be considered secondary results. Organic vapor results are from ORNL, with semiquantitative values in parentheses and quantitative values not in parentheses.

2 Data are from Huckaby $1995 \mathrm{~b}$.

3 Data are from Huckaby 1995 c. 
WHC-SD-WM-ER-445 Rev. 1

Table 4-1

Tank C-107 Quantitatively Measured Organic Compounds in SUMMA ${ }^{\text {TM Samples - }}$ Analyses by Pacific Northwest Laboratory

\begin{tabular}{clcccc}
\hline $\begin{array}{c}\text { Cmpd } \\
\#\end{array}$ & Compound & $\begin{array}{c}\text { CAS }^{1} \\
\text { Number }\end{array}$ & $\begin{array}{c}\text { Average }^{2} \\
\text { (ppmv) }\end{array}$ & $\begin{array}{c}\text { Standard } \\
\text { Deviation } \\
\text { (ppmv) }\end{array}$ & $\begin{array}{c}\text { RSD }^{3} \\
(\%)\end{array}$ \\
\hline 1 & Methane & & \\
2 & 2-Butanone & $74-82-8$ & {$[3.4]$} & {$[<0.06]$} & {$[<2]$} \\
3 & Propanone (acetone) & $78-93-3$ & 0.011 & 0.003 & 27 \\
4 & Ethanenitrile (acetonitrile) & $67-64-1$ & 0.83 & 0.07 & 8 \\
\hline \hline
\end{tabular}

$1 \mathrm{CAS}=$ Chemical Abstract Service.

2 Average of 3 samples.

3 RSD = relative standard deviation. Burnum (1995) specifies the RSD should be less than $25 \%$.

4 Methane analyses were performed by OGIST and should be considered a secondary result (Rasmussen 1994). 
Table 4-2

Tank C-107 Quantitatively Measured Organic Compounds in TST Samples -Analyses by Oak Ridge National Laboratory ${ }^{\dagger}$

\begin{tabular}{clcccc}
\hline $\begin{array}{c}\text { Cmpd } \\
\#\end{array}$ & Compound & $\begin{array}{c}\text { CAS }^{2} \\
\text { Number }\end{array}$ & $\begin{array}{c}\text { Average } \\
\text { (ppmv) }\end{array}$ & $\begin{array}{c}\text { Standard } \\
\text { Deviation } \\
\text { (ppmv) }\end{array}$ & $\begin{array}{c}\text { RSD }^{4} \\
(\%)\end{array}$ \\
\hline \hline 1 & Propanenitrile & $107-12-0$ & 0.064 & 0.020 & 32 \\
2 & n-Butanenitrile & $109-74-0$ & 0.012 & 0.003 & 28 \\
3 & n-Pentanenitrile & $110-59-8$ & 0.0085 & 0.0020 & 24 \\
4 & n-Undecane & $1120-21-4$ & 0.0056 & 0.0006 & 10 \\
5 & n-Dodecane & $112-40-3$ & 0.0073 & 0.0005 & 6 \\
6 & n-Tridecane & $629-50-5$ & 0.0092 & 0.0012 & 13 \\
\hline \hline
\end{tabular}

1 Results in this table are quantitative (as defined in Section 4.1).

$2 \mathrm{CAS}=$ Chemical Abstract Service .

3 Average of 3, 2-L TST samples.

4 RSD = relative standard deviation. Burnum (1995) specifies the RSD should be less than $25 \%$. 
WHC-SD-WM-ER-445 Rev. 1

Table 4-3

Tank C-107 Positively Identified Organic Compounds in TST Samples -Analyses by Oak Ridge National Laboratory'

\begin{tabular}{|c|c|c|c|c|c|}
\hline$\underset{\#}{\text { Cmpd }}$ & Compound & $\begin{array}{c}\mathrm{CAS}^{2} \\
\text { Number }\end{array}$ & $\begin{array}{c}\text { Average }^{3} \\
\text { (ppmv) }\end{array}$ & $\begin{array}{c}\text { Standard } \\
\text { Deviation } \\
\text { (ppmv) }\end{array}$ & $\begin{array}{c}\mathrm{RSD}^{4} \\
(\%)\end{array}$ \\
\hline 1 & Ethanenitrile (acetonitrile) & $75-05-8$ & 0.25 & 0.10 & 39 \\
\hline 2 & Propanone (acetone) & $67-64-1$ & 0.094 & 0.090 & 96 \\
\hline 3 & $\begin{array}{l}\text { Dichloromethane (methylene } \\
\text { chloride) }\end{array}$ & $75-09-2$ & 0.14 & 0.24 & 167 \\
\hline 4 & n-Hexane & $110-54-3$ & $<0.0013$ & - & - \\
\hline 5 & Benzene & $71-43-2$ & $<0.00086$ & - & - \\
\hline 6 & n-Heptane & $142-82-5$ & 0.0012 & 0.0014 & 113 \\
\hline 7 & Toluene & $108-88-3$ & 0.00066 & 0.00030 & 45 \\
\hline 8 & 2-Hexanone & $591-78-6$ & 0.0013 & 0.0003 & 26 \\
\hline 9 & n-Octane & $111-65-9$ & 0.0012 & 0.0005 & 41 \\
\hline 10 & n-Hexanenitrile & $628-73-9$ & 0.0051 & 0.0009 & 17 \\
\hline 11 & 2-Heptanone & $110-43-0$ & 0.0011 & 0.0005 & 45 \\
\hline 12 & n-Nonane & $111-84-2$ & $<0.0011$ & - & - \\
\hline 13 & n-Heptanenitrile & $629-08-3$ & 0.0028 & 0.0010 & 36 \\
\hline 14 & 2-Octanone & $111-13-7$ & $<0.00079$ & - & - \\
\hline 15 & n-Decane & $124-18-5$ & $<0.0027$ & - & -- \\
\hline
\end{tabular}

1 Results in this table are not quantitative (as defined in Section 4.1 ) because measured values in at least 1 of the samples are outside instrument calibration limits.

2 CAS $=$ Chemical Abstract Service.

3 Average of 3, 2-L TST samples.

$4 \mathrm{RSD}=$ relative standard deviation. Burnum (1995) specifies the RSD should be less than $25 \%$. 
WHC-SD-WM-ER-445 Rev. 1

Table 4-4

Tank C-107 Positively Identified Compounds in TST Samples for which Practical Holding Times were Exceeded Analyses by Oak Ridge National Laboratory'

\begin{tabular}{clrrrr}
\hline $\begin{array}{c}\text { Cmpd } \\
\#\end{array}$ & Compound & $\begin{array}{c}\text { CAS }^{2} \\
\text { Number }\end{array}$ & $\begin{array}{c}\text { Average } \\
\text { (ppmv) }\end{array}$ & $\begin{array}{c}\text { Standard } \\
\text { Deviation } \\
\text { (ppmv) }\end{array}$ & $\begin{array}{c}\mathrm{RSD}^{4} \\
(\%)\end{array}$ \\
\hline 1 & Butanat $^{5}$ & $123-72-8$ & $<0.0016$ & - & - \\
2 & $1-$ Butanol $^{5}$ & $71-36-3$ & 0.0025 & 0.0009 & 36 \\
3 & 2-Pentanone & $107-87-9$ & 0.0022 & 0.0022 & 100 \\
\hline
\end{tabular}

1 Practical holding times are defined and discussed in Section 4.1.

$2 \mathrm{CAS}=$ Chemical Abstract Service.

3 Average of 3, 2-L. TST samples.

4 RSD = relative standard deviation. Burnum (1995) specifies the RSD should be less than $25 \%$.

5 The concentration of this analyte was not quantitatively measured (as defined in Section 4.1), because the measured concentration was outside of the instrumental calibration limits. 
Table 4.5

Tank C-107 Comparison of Organic Compounds in TST and SUMMA ${ }^{\text {TM Samples - }}$ Analyses by Pacific Northwest Laboratory and Oak Ridge National Laboratory

\begin{tabular}{|c|c|c|c|c|}
\hline Compound & $\begin{array}{c}\mathrm{CAS}^{1} \\
\text { Number }\end{array}$ & $\begin{array}{c}\text { TST } \\
\text { Average }^{2} \\
\text { (ppmv) }\end{array}$ & $\begin{array}{l}\text { SUMMA' } \\
\text { Average }^{3} \\
\text { (ppmv) }\end{array}$ & $\begin{array}{l}\text { PRD }^{4} \\
(\%)\end{array}$ \\
\hline $\begin{array}{l}\text { 1,1-Dichloroethene (vinylidene } \\
\text { chloride) }\end{array}$ & $75-35-4$ & $<0.00058$ & $<0.005$ & - \\
\hline Dichloromethane (methylene chloride) & $75-08-2$ & 0.14 & $<0.005$ & $>186$ \\
\hline Propanone (acetone) & $67-64-1$ & 0.094 & 0.83 & 159 \\
\hline Ethanenitrile (acetonitrile) & $75-05-8$ & 0.25 & 0.64 & 88 \\
\hline Propanenitrile & $107-12-0$ & 0.064 & $<0.005$ & $>171$ \\
\hline n-Butanenitrile & $109-74-0$ & 0.012 & $<0.005$ & $>82$ \\
\hline Benzene & $71-43-2$ & $<0.00086$ & $<0.005$ & - \\
\hline Toluene & $108-88-3$ & 0.00066 & $<0.005$ & - \\
\hline n-Hexane & $110-54-3$ & $<0.0013$ & $<0.005$ & - \\
\hline n-Heptane & $142-82-5$ & 0.0012 & $<0.005$ & - \\
\hline n-Decane & $124-18-5$ & $<0.0027$ & $<0.005$ & - \\
\hline
\end{tabular}

$1 \mathrm{CAS}=$ Chemical Abstract Service.

2 Average of 3, 2-L TST samples.

3 Average of 3 samples.

4 PRD = percent relative difference. Keller (1994) requires the PRD to be less than $20 \%$. 
WHC-SD-WM-ER-445 ReV. 1

Table 4-6

Tank C-107 Tentatively Identified Organic Compounds in SUMMA TW Samples -Analyses by Pacific Northwest Laboratory

\begin{tabular}{clcrc}
\hline $\begin{array}{c}\text { Cmpd } \\
\#\end{array}$ & Compound & $\begin{array}{c}\text { CAS }^{1} \\
\text { Number }\end{array}$ & $\begin{array}{c}\text { Average }^{2} \\
\left(\mathrm{mg}^{3} \mathrm{~m}^{3}\right)\end{array}$ & $\begin{array}{c}\text { Standard } \\
\text { Deviation } \\
\left(\mathrm{mg} / \mathrm{m}^{3}\right)\end{array}$ \\
\hline 1 & Cyclopropane \\
2 & Acetaldehyde & $75-19-4$ & 0.15 & 0.01 \\
3 & Methyl Nitrate & $75-07-0$ & 0.09 & 0.01 \\
4 & Unknown Alkane & $598-58-3$ & 0.19 & 0.01 \\
5 & Unknown Alkane & & 0.13 & 0.01 \\
6 & Nitric Acid, Ethyl Ester & & 0.18 & 0.02 \\
7 & Unknown Alkane & $625-58-1$ & 0.23 & 0.01 \\
8 & n-Dodecane & & 0.12 & 0.01 \\
9 & n-Tridecane & $112-40-3$ & 0.24 & 0.23 \\
10 & n-Tetradecane & $629-50-5$ & 1.18 & 1.26 \\
\hline \hline
\end{tabular}

$1 \mathrm{CAS}=$ Chemical Abstract Service.

2 Based on analyses of 3 samples; presented values are estimates.

3 When the analyte was detected in only 2 samples, the entry is the relative difference (i.e., their difference divided by 2).

4 Detected in only 2 samples. 
Table 4-7

Tank C-107 Tentatively Identified Organic Compounds in TST Samples in Order of Chromatographic Elution -Analyses by Oak Ridge National Laboratory

\begin{tabular}{|c|c|c|c|c|}
\hline$\underset{\#}{\text { Cmpd }}$ & Compound & $\begin{array}{c}\text { CAS }^{1} \\
\text { Number }\end{array}$ & $\begin{array}{c}\text { Average }^{2} \\
\left(\mathrm{mg} / \mathrm{m}^{3}\right)\end{array}$ & $\begin{array}{c}\text { Standard } \\
\text { Deviation } \\
\left(\mathrm{mg} / \mathrm{m}^{3}\right)\end{array}$ \\
\hline 1 & Methane, oxybis & $115-10-6$ & 0.044 & 0.012 \\
\hline 2 & Methane, trichlorofluoro & $75-69-4$ & 0.049 & 0.039 \\
\hline 3 & nitro compound & & 0.021 & 0.020 \\
\hline 4 & 1-Propene, 2-fiuoro and others & & 0.0080 & 0.0140 \\
\hline 5 & 2-Butanone & $78-93-3$ & 0.0089 & 0.0154 \\
\hline 6 & Nitric acid, ethyl ester & $625-58-1$ & 0.051 & 0.010 \\
\hline 7 & Butane, 1-chloro & $109-69-3$ & 0.030 & 0.006 \\
\hline 8 & Cyclopropanecarbonitrile & $5500-21-0$ & 0.0072 & 0.0124 \\
\hline 9 & 2-Butanenitrile and others & & 0.0025 & 0.0044 \\
\hline 10 & Hexane, 2,3-dimethyl & $584-94-1$ & 0.0048 & 0.0083 \\
\hline 11 & Nitric acid, propyl ester & $627-13-4$ & 0.0057 & 0.0099 \\
\hline 12 & Mixture & & 0.0063 & 0.0056 \\
\hline 13 & Acetic acid & $64-19-7$ & 0.16 & 0.17 \\
\hline 14 & Acetic acid & $64-19-7$ & 0.067 & 0.115 \\
\hline 15 & 1-Pentene & $109-67-1$ & 0.011 & 0.019 \\
\hline 16 & Propane, 2-methyl-2-nitro & $594-70-7$ & 0.034 & 0.030 \\
\hline 17 & Acetic acid & $64-19-7$ & 0.031 & 0.053 \\
\hline 18 & Cyclopropane, 1,2-dimethyl, cis & $930-18-7$ & 0.011 & 0.010 \\
\hline 19 & 1H-Pyrrole & $109-97-7$ & 0.0040 & 0.0070 \\
\hline 20 & Ethene, $1,1^{\prime}$-oxybis & $109-93-3$ & 0.0056 & 0.0097 \\
\hline 21 & Ethene, 1,1'-oxybis & $109-93-3$ & 0.027 & 0.047 \\
\hline 22 & Oxirane, ethenyl & $930-22-3$ & 0.019 & 0.002 \\
\hline 23 & Hexanal & $66-25-1$ & 0.0045 & 0.0078 \\
\hline 24 & Propane, 2-methyl-2-nitro & $594-70-7$ & 0.015 & 0.003 \\
\hline 25 & Cyclotrisiloxane, hexamethyl & $541-05-9$ & 0.27 & 0.23 \\
\hline 26 & Nitric acid, propyl ester & $627-13-4$ & 0.019 & 0.017 \\
\hline
\end{tabular}




\begin{tabular}{|c|c|c|c|c|}
\hline$\underset{\#}{C \operatorname{Cmpd}}$ & Compound & $\begin{array}{c}\mathrm{CAS}^{1} \\
\text { Number }\end{array}$ & $\begin{array}{c}\text { Average } \\
\left(\mathrm{mg} / \mathrm{m}^{3}\right)\end{array}$ & $\begin{array}{c}\text { Standard } \\
\text { Deviation } \\
\left(\mathrm{mg} / \mathrm{m}^{3}\right)\end{array}$ \\
\hline 27 & Nitric acid, butyl ester & $928-45-0$ & 0.0039 & 0.0067 \\
\hline 28 & Methylamine, N-(1-methylbutylidene)- & $22431-09-0$ & 0.0061 & 0.0106 \\
\hline 29 & Pyrazine, methyl & $109-08-0$ & 0.0033 & 0.0057 \\
\hline 30 & Benzene, ethyl & $100-41-4$ & 0.0013 & 0.0022 \\
\hline 31 & Benzene, 1,2-dimethyl & $95-47-6$ & 0.0036 & 0.0031 \\
\hline 32 & 3-Heptanone & $106-35-4$ & 0.0022 & 0.0038 \\
\hline 33 & Butane, 2-bromo & $78-76-2$ & 0.0034 & 0.0059 \\
\hline 34 & Heptanal & $111-71-7$ & 0.0048 & 0.0005 \\
\hline 35 & 1,5-Pentanediol, dinitrate & $3457-92-9$ & 0.0040 & 0.0003 \\
\hline 36 & 2(3H)-furanone, dihydro and C3-benzene & & 0.0013 & 0.0022 \\
\hline 37 & Mixture & & 0.0016 & 0.0027 \\
\hline 38 & 2-Heptanone, 6-methyl & $928-68-7$ & 0.0027 & 0.0024 \\
\hline 39 & Hexane 3,4-dimethyl and others & & 0.0032 & 0.0029 \\
\hline 40 & 2(3H)-Furanone, dihydro-5-methyl & $108-29-2$ & 0.0012 & 0.0020 \\
\hline 41 & Alkenol & & 0.0050 & 0.0087 \\
\hline 42 & 4-Octanone & $589-63-9$ & 0.0017 & 0.0030 \\
\hline 43 & Phenol and 1-propenyl benzene & & 0.0034 & 0.0059 \\
\hline 44 & Mixture & & 0.0019 & 0.0033 \\
\hline 45 & 5-Hepten-2-one, 6-methyl & $110-93-0$ & 0.0023 & 0.0040 \\
\hline 46 & Cyclotetrasiloxane, octamethyl & $556-67-2$ & 0.060 & 0.037 \\
\hline 47 & Octanal & $124-13-0$ & 0.0082 & 0.0016 \\
\hline 48 & Nitric acid, butyl ester & $928-45-0$ & 0.010 & 0.003 \\
\hline 49 & 1-Hexanol, 2-ethyl & $104-76-7$ & 0.0015 & 0.0026 \\
\hline 50 & 3-Hexene-2-one and others & & 0.0034 & 0.0029 \\
\hline 51 & 2(3H)-Furanone, 5-ethyldihydro & $695-06-7$ & 0.0034 & 0.0030 \\
\hline 52 & 2H-pyran-3(4H)-one, dihydro & $23462-75-1$ & 0.0032 & 0.0028 \\
\hline 53 & 4-Nonanone & $4485-09-0$ & 0.0015 & 0.0026 \\
\hline 54 & Cyclopropane, pentyl & $2511-91-3$ & 0.0015 & 0.0026 \\
\hline
\end{tabular}




\begin{tabular}{|c|c|c|c|c|}
\hline $\begin{array}{l}\text { Cmpd } \\
\#\end{array}$ & Compound & $\begin{array}{l}\text { CAS }^{1} \\
\text { Number }\end{array}$ & $\begin{array}{c}\text { Average }^{2} \\
\left(\mathrm{mg} / \mathrm{m}^{3}\right)\end{array}$ & $\begin{array}{l}\text { Standard } \\
\text { Deviation } \\
\left(\mathrm{mg} / \mathrm{m}^{3}\right)\end{array}$ \\
\hline 55 & Ethanone, 1-phenyl & $98-86-2$ & 0.0049 & 0.0045 \\
\hline 56 & Octanenitrile & $124-12-9$ & 0.021 & 0.006 \\
\hline 57 & 4-Undecene, (E)- & $693-62-9$ & 0.0014 & 0.0023 \\
\hline 58 & 2-Nonanone & $821-55-6$ & 0.0060 & 0.0053 \\
\hline 59 & Nonanal & $124-19-6$ & 0.011 & 0.001 \\
\hline 60 & 1,3-Benzenediol, 2-methyl & $608-25-3$ & 0.0037 & 0.0033 \\
\hline 61 & Nitric acid, hexyl ester & $20633-11-8$ & 0.0081 & 0.0007 \\
\hline 62 & Benzeneacetic acid, a-4-bis[(trimethylsilyl) & $37148-64-4$ & 0.0047 & 0.0042 \\
\hline 63 & $\begin{array}{l}\text { Cyclohexanone,2,5-dimethyl-2-(1-methyle } \\
\mathrm{t}\end{array}$ & $6711-26-8$ & 0.0011 & 0.0020 \\
\hline 64 & 2(3H)-Furanone, dihydro-5-propyl & $105-21-5$ & 0.0082 & 0.0018 \\
\hline 65 & Decane, 2-methyl & $6975-98-0$ & 0.0078 & 0.0067 \\
\hline 66 & 5-Undecanone, 2-methyl & $50639-02-6$ & 0.0041 & 0.0071 \\
\hline 67 & Nonanenitrile & $2243-27-8$ & 0.017 & 0.009 \\
\hline 68 & 4-Dodecene & $7206-15-7$ & 0.0068 & 0.0023 \\
\hline 69 & 1-Dodecene & $112-41-4$ & 0.0016 & 0.0029 \\
\hline 70 & 2-Decanone & $693-54-9$ & 0.0059 & 0.0008 \\
\hline 71 & Naphthalene & $91-20-3$ & 0.0010 & 0.0017 \\
\hline 72 & 4-Dodecene, cis=trans & & 0.0029 & 0.0031 \\
\hline 73 & Decanal & $112-31-2$ & 0.0089 & 0.0010 \\
\hline 74 & 1,3-Benzodioxal-2-one, hexahydro & $20192-66-9$ & 0.0025 & 0.0004 \\
\hline 75 & Benzene, 1-chloro-4-nitro & $100-00-5$ & 0.0052 & 0.0011 \\
\hline 76 & $2(3 H)$-furanone, 5 -butyldihydro & $104-50-7$ & 0.0028 & 0.0027 \\
\hline 77 & 1,3,5,7-Tetraazatricyclo[3.3.1.13.7]decane & $100-97-0$ & 0.0023 & 0.0040 \\
\hline 78 & 5-Undecanone & $33083-83-9$ & 0.012 & 0.003 \\
\hline 79 & alkyl-cyclopentane & & 0.0017 & 0.0029 \\
\hline 80 & alkyl nitrile & & 0.019 & 0.004 \\
\hline 81 & 2-Undecanone & $112-12-9$ & 0.0076 & 0.0025 \\
\hline 82 & 1-Tridecene & $2437-56-1$ & 0.00080 & 0.00139 \\
\hline
\end{tabular}




\begin{tabular}{|c|c|c|c|c|}
\hline$\underset{\#}{\text { Cmpd }}$ & Compound & $\begin{array}{c}\mathrm{CAS}^{1} \\
\text { Number }\end{array}$ & $\begin{array}{l}\text { Average }^{2} \\
\left(\mathrm{mg} / \mathrm{m}^{3}\right)\end{array}$ & $\begin{array}{c}\text { Standard } \\
\text { Deviation } \\
\left(\mathrm{mg} / \mathrm{m}^{3}\right)\end{array}$ \\
\hline 83 & 1-Tridecene & $2437-56-1$ & 0.00070 & 0.00122 \\
\hline 84 & Tridecanal & 10486-19-8 & 0.00066 & 0.00114 \\
\hline 85 & 6-Dodecanone & $6064-27-3$ & 0.0072 & 0.0024 \\
\hline 86 & Decane, 5-propyl-and others & & 0.013 & 0.003 \\
\hline 87 & 1H-Inden-1-one, 2,3-dihydro-3,3-dimethyl & $26465-81-6$ & 0.00098 & 0.0017 \\
\hline 88 & 3-Octanone & $106-68-3$ & 0.0010 & 0.0018 \\
\hline 89 & 3-Dodecanone & $1534-27-6$ & 0.013 & 0.0026 \\
\hline 90 & Tetradecane & $629-59-4$ & 0.025 & 0.005 \\
\hline 91 & 3-Octen-2-ol, 2-methyl, cis & $18521-07-8$ & 0.0024 & 0.0021 \\
\hline 92 & Cyclohexanone, 4-hydroxy-4-methyl & $17429-02-6$ & 0.00082 & 0.00142 \\
\hline 93 & 5,9-Undecadien-2-one,6,10-dimethyl (Z) & $3879-26-3$ & 0.0069 & 0.0029 \\
\hline 94 & 5-Undecanone, 2-methyl & $50639-02-6$ & 0.012 & 0.002 \\
\hline 95 & $\begin{array}{l}\text { 2,5-Cyclohexadiene, 1,4-dione, } \\
\text { 2,6-bis }(1,1\end{array}$ & $719-22-2$ & 0.0077 & 0.0025 \\
\hline 96 & 3-Tridecanone & $1534-26-5$ & 0.011 & 0.002 \\
\hline 97 & 2-Tridecanone & $593-08-8$ & 0.0084 & 0.0065 \\
\hline 98 & 2-Pentene, 5-(pentyloxy)- (E)- & $56052-85-8$ & 0.0013 & 0.0023 \\
\hline 99 & Cyclohexadecane & $295-65-8$ & 0.0019 & 0.0019 \\
\hline 100 & Dodecanoic acid & $143-07-7$ & 0.014 & 0.002 \\
\hline 101 & 5-Undecanone, 2-methyl & $50639-02-6$ & 0.0033 & 0.0008 \\
\hline 102 & Mixture & & 0.0022 & 0.0020 \\
\hline 103 & 3-Dodecanone & $1534-27-6$ & 0.00064 & 0.00110 \\
\hline 104 & Undecane, 3,8-dimethyl & $17301-30-3$ & 0.00065 & 0.00112 \\
\hline 105 & Alkanone & & 0.0015 & 0.0013 \\
\hline 106 & Mixture & & 0.00095 & 0.00164 \\
\hline 107 & $\begin{array}{l}\text { Butyric acid, ester w/ } \\
\text { p-hydroxybenzonitrile }\end{array}$ & $29052-10-6$ & 0.00094 & 0.00162 \\
\hline 108 & Phthalate & & 0.0055 & 0.0056 \\
\hline
\end{tabular}




\begin{tabular}{|c|c|c|c|c|}
\hline Cmpd & Compound & $\begin{array}{l}\text { CAS }^{1} \\
\text { Number }\end{array}$ & $\begin{array}{l}\text { Average }^{2} \\
\left(\mathrm{mg} / \mathrm{m}^{3}\right)\end{array}$ & $\begin{array}{c}\text { Standard } \\
\text { Deviation } \\
\left(\mathrm{mg} / \mathrm{m}^{3}\right)\end{array}$ \\
\hline 109 & $\begin{array}{l}\text { Tributyl phosphate and benzenamine, } \\
\text { N-phenyl }\end{array}$ & & 0.0068 & 0.0028 \\
\hline 110 & 3-Phenoxybenzaldehyde & $39515-51-0$ & 0.0014 & 0.0012 \\
\hline 111 & Hexanedioic acid, bis-(1-methylpropyl)-est & $38447-22-2$ & 0.00064 & 0.00111 \\
\hline 112 & 1-Dodecanol & $112-53-8$ & 0.00073 & 0.00127 \\
\hline 113 & Heptadecane, 8-methyl & $13287-23-5$ & 0.00069 & 0.00119 \\
\hline 114 & 9-Octadecenoic acid, (Z)- & $112-80-1$ & 0.00064 & 0.00112 \\
\hline 115 & 9-Octadecenoic acid, (Z)- & $112-80-1$ & 0.0036 & 0.0063 \\
\hline 116 & Tetradecanoic acid & $544-63-8$ & 0.031 & 0.051 \\
\hline 117 & Benzamide, N-methyl & $613-93-4$ & 0.00079 & 0.0014 \\
\hline 118 & 9-Octadecenoic acid, methyl ester (E) & $1937-62-8$ & 0.0055 & 0.0050 \\
\hline 119 & Tetradecanoic acid & $544-63-8$ & 0.057 & 0.049 \\
\hline 120 & 1-Hexadecanol & $36653-82-4$ & 0.0083 & 0.014 \\
\hline 121 & Alkane and Alkanoic acid & & 0.0011 & 0.0019 \\
\hline 122 & $\begin{array}{l}\text { Hexadecanoic acid, } \\
\text { 2,3-dihydroxypropyles }\end{array}$ & $542-44-9$ & 0.0027 & 0.0023 \\
\hline 123 & Benzenesulfonamide, N-butyl & $3622-84-2$ & 0.091 & 0.015 \\
\hline 124 & Eicosane & $112-95-8$ & 0.0042 & 0.0074 \\
\hline 125 & Tetradecanoic acid, 12-methyl, cis & $5746-58-7$ & 0.0063 & 0.0054 \\
\hline 126 & 9-Octadecenoic acid, (Z)- & $112-80-1$ & 0.0023 & 0.0041 \\
\hline 127 & Alkane & & 0.0054 & 0.0093 \\
\hline 128 & Hexanedioic acid, dioctyl ester & $123-79-5$ & 0.047 & 0.081 \\
\hline 129 & 14-Pentadecenoic acid & $17351-34-7$ & 0.0067 & 0.0069 \\
\hline 130 & Pentadecanoic acid & $1002-84-2$ & 0.029 & 0.026 \\
\hline 131 & 1-Hexadecanol & $36653-82-4$ & 0.0068 & 0.0061 \\
\hline 132 & 1-Hexadecene & $629-73-2$ & 0.0043 & 0.0075 \\
\hline 133 & 1-Octadecanol & $112-92-5$ & 0.0089 & 0.015 \\
\hline 134 & Nonadecane & $629-92-5$ & 0.00087 & 0.00152 \\
\hline 135 & 9-Hexadecenoic acid & $2091-29-4$ & 0.090 & 0.009 \\
\hline
\end{tabular}


WHC-SD-WM-ER-445 Rev. 1

\begin{tabular}{clrcc}
\hline $\begin{array}{c}\text { Cmpd } \\
\#\end{array}$ & Compound & $\begin{array}{c}\text { CAS } \\
\text { Number }\end{array}$ & $\begin{array}{c}\text { Average } \\
\left(\mathrm{mg} / \mathrm{m}^{3}\right)\end{array}$ & $\begin{array}{c}\text { Standard } \\
\text { Deviation } \\
\left(\mathrm{mg}^{3} \mathrm{~m}^{3}\right.\end{array}$ \\
\hline \hline 136 & Hexadecanoic acid & $57-10-3$ & 0.12 & 0.06 \\
137 & Eicosane & $112-95-8$ & 0.0014 & 0.0025 \\
138 & 1-Hexadecanol & $36653-82-4$ & 0.0025 & 0.0044 \\
139 & 1-Hexadecanol, acetate & $629-70-9$ & 0.0030 & 0.0028 \\
140 & Hexadecanoic acid & $57-10-3$ & 0.024 & 0.006 \\
141 & 1-Hexadecanol & $36653-82-4$ & 0.043 & 0.038 \\
142 & 1-Octadecanol & $112-92-5$ & 0.027 & 0.046 \\
143 & Heptadecane, 2,6,10,15-tetramethyl & $54833-48-6$ & 0.0025 & 0.0044 \\
144 & Heneicosane & $629-94-7$ & 0.0043 & 0.0075 \\
145 & Pentadecane, 8-hexyl & $13475-75-7$ & 0.0035 & 0.0061 \\
\hline \hline Sum of tentatively identified compounds: & & 2.04 & \\
\hline \hline
\end{tabular}

$1 \mathrm{CAS}=$ Chemical Abstract Service .

2 Average of 3, 2-L TST samples; presented values are estimates. 
WHC-SD-WM-ER-445 Rev. 1

Table 4-8

Tank C-107 Tentatively Identified Organic Compounds in TST Samples Sorted Alphanumerically -Analyses by Oak Ridge National Laboratory

\begin{tabular}{|c|c|c|c|c|}
\hline$\underset{\#}{\text { Cmpd }}$ & Compound & $\begin{array}{c}\text { CAS }^{1} \\
\text { Number }\end{array}$ & $\begin{array}{l}\text { Average } 2 \\
{ }^{2}\left(\mathrm{mg} / \mathrm{m}^{3}\right)\end{array}$ & $\begin{array}{c}\text { Standard } \\
\text { Deviation } \\
\left(\mathrm{mg} / \mathrm{m}^{3}\right)\end{array}$ \\
\hline 120 & 1-Hexadecanol & $36653-82-4$ & 0.0083 & 0.014 \\
\hline 112 & 1-Dodecanol & $112-53-8$ & 0.00073 & 0.00127 \\
\hline 49 & 1-Hexanol, 2-ethyl & $104-76-7$ & 0.0015 & 0.0026 \\
\hline 4 & 1-Propene, 2-filuoro and others & & 0.0080 & 0.0140 \\
\hline 131 & 1-Hexadecanol & $36653-82-4$ & 0.0068 & 0.0061 \\
\hline 142 & 1-Octadecanol & $112-92-5$ & 0.027 & 0.046 \\
\hline 132 & 1-Hexadecene & $629-73-2$ & 0.0043 & 0.0075 \\
\hline 133 & 1-Octadecanol & $112-92-5$ & 0.0089 & 0.015 \\
\hline 139 & 1-Hexadecanol, acetate & $629-70-9$ & 0.0030 & 0.0028 \\
\hline 69 & 1-Dodecene & $112-41-4$ & 0.0016 & 0.0029 \\
\hline 141 & 1-Hexadecanol & $36653-82-4$ & 0.043 & 0.038 \\
\hline 83 & 1-Tridēcene & $2437-56-1$ & 0.00070 & 0.00122 \\
\hline 82 & 1-Tridecene & $2437-56-1$ & 0.00080 & 0.00139 \\
\hline 138 & 1-Hexadecanol & $36653-82-4$ & 0.0025 & 0.0044 \\
\hline 15 & 1-Pentene & $109-67-1$ & 0.011 & 0.019 \\
\hline 60 & 1,3-Benzenediol, 2-methyl & $608-25-3$ & 0.0037 & 0.0033 \\
\hline 74 & 1,3-Benzodioxal-2-one, hexahydro & $20192-66-9$ & 0.0025 & 0.0004 \\
\hline 35 & 1,5-Pentanediol, dinitrate & $3457-92-9$ & 0.0040 & 0.0003 \\
\hline 77 & 1,3,5,7-Tetraazatricyclo[3.3.1.13.7]decane & $100-97-0$ & 0.0023 & 0.0040 \\
\hline 129 & 14-Pentadecenoic acid & $17351-34-7$ & 0.0067 & 0.0069 \\
\hline 19 & 1H-Pyrrole & $109-97-7$ & 0.0040 & 0.0070 \\
\hline 87 & 1H-Inden-1-one, 2,3-dihydro-3,3-dimethyl & $26465-81-6$ & 0.00098 & 0.0017 \\
\hline 70 & 2-Decanone & $693-54-9$ & 0.0059 & 0.0008 \\
\hline 81 & 2-Undecanone & $112-12-9$ & 0.0076 & 0.0025 \\
\hline 98 & 2-Pentene, 5-(pentyloxy)- (E)- & $56052-85-8$ & 0.0013 & 0.0023 \\
\hline 9 & 2-Butanenitrile and others & & 0.0025 & 0.0044 \\
\hline
\end{tabular}


WHC-SD-WM-ER-445 Rev. 1

\begin{tabular}{|c|c|c|c|c|}
\hline Cmpd & Compound & $\begin{array}{c}\mathrm{CAS}^{1} \\
\text { Number }\end{array}$ & $\begin{array}{c}\text { Average }^{2} \\
\left(\mathrm{mg} / \mathrm{m}^{3}\right)\end{array}$ & $\begin{array}{l}\text { Standard } \\
\text { Deviation } \\
\left(\mathrm{mg} / \mathrm{m}^{3}\right)\end{array}$ \\
\hline 58 & 2-Nonanone & $821-55-6$ & 0.0060 & 0.0053 \\
\hline 5 & 2-Butanone & $78-93-3$ & 0.0089 & 0.0154 \\
\hline 97 & 2-Tridecanone & $593-08-8$ & 0.0084 & 0.0065 \\
\hline 38 & 2-Heptanone, 6-methyl & $928-68-7$ & 0.0027 & 0.0024 \\
\hline 95 & $\begin{array}{l}\text { 2,5-Cyclohexadiene, 1,4-dione, } \\
\text { 2,6-bis }(1,1\end{array}$ & $719-22-2$ & 0.0077 & 0.0025 \\
\hline 51 & 2(3H)-Furanone, 5-ethyldihydro & $695-06-7$ & 0.0034 & 0.0030 \\
\hline 64 & 2(3H)-Furanone, dihydro-5-propyl & $105-21-5$ & 0.0082 & 0.0018 \\
\hline 76 & 2(3H)-furanone, 5-butyldihydro & $104-50-7$ & 0.0028 & 0.0027 \\
\hline 40 & 2(3H)-Furanone, dihydro-5-methyl & $108-29-2$ & 0.0012 & 0.0020 \\
\hline 36 & 2(3H)-furanone, dihydro and C3-benzene & & 0.0013 & 0.0022 \\
\hline 52 & 2H-pyran-3(4H)-one, dihydro & $23462-75-1$ & 0.0032 & 0.0028 \\
\hline 32 & 3-Heptanone & $106-35-4$ & 0.0022 & 0.0038 \\
\hline 110 & 3-Phenoxybenzaldehyde & $39515-51-0$ & 0.0014 & 0.0012 \\
\hline 91 & 3-Octen-2-ol, 2-methyl, cis & $18521-07-8$ & 0.0024 & 0.0021 \\
\hline 88 & 3-Octanone & $106-68-3$ & 0.0010 & 0.0018 \\
\hline 50 & 3-Hexene-2-one and others & & 0.0034 & 0.0029 \\
\hline 89 & 3-Dodecanone & $1534-27-6$ & 0.013 & 0.0026 \\
\hline 103 & 3-Dodecanone & $1534-27-6$ & 0.00064 & 0.00110 \\
\hline 96 & 3-Tridecanone & $1534-26-5$ & 0.011 & 0.002 \\
\hline 68 & 4-Dodecene & $7206-15-7$ & 0.0068 & 0.0023 \\
\hline 42 & 4-Octanone & $589-63-9$ & 0.0017 & 0.0030 \\
\hline 72 & 4-Dodecene, cis=trans & & 0.0029 & 0.0031 \\
\hline 57 & 4-Undecene, (E)- & $693-62-9$ & 0.0014 & 0.0023 \\
\hline 53 & 4-Nonanone & $4485-09-0$ & 0.0015 & 0.0026 \\
\hline 78 & 5-Undecanone & $33083-83-9$ & 0.012 & 0.003 \\
\hline 66 & 5-Undecanone, 2-methyl & $50639-02-6$ & 0.0041 & 0.0071 \\
\hline 45 & 5-Hepten-2-one, 6-methyl & $110-93-0$ & 0.0023 & 0.0040 \\
\hline 94 & 5-Undecanone, 2-methyl & $50639-02-6$ & 0.012 & 0.002 \\
\hline & 32 & & & \\
\hline
\end{tabular}




\begin{tabular}{|c|c|c|c|c|}
\hline Cmpd & Compound & $\begin{array}{c}\text { CAS }^{1} \\
\text { Number }\end{array}$ & $\begin{array}{l}\text { Average }{ }^{2} \\
\left(\mathrm{mg} / \mathrm{m}^{3}\right)\end{array}$ & $\begin{array}{c}\text { Standard } \\
\text { Deviation } \\
\left(\mathrm{mg} / \mathrm{m}^{3}\right)\end{array}$ \\
\hline 101 & 5-Undecanone, 2-methyl & $50639-02-6$ & 0.0033 & 0.0008 \\
\hline 93 & 5,9-Undecadien-2-one,6,10-dimethyl (Z) & $3879-26-3$ & 0.0069 & 0.0029 \\
\hline 85 & 6-Dodecanone & $6064-27-3$ & 0.0072 & 0.0024 \\
\hline 135 & 9-Hexadecenoic acid & $2091-29-4$ & 0.090 & 0.009 \\
\hline 126 & 9-Octadecenoic acid, (Z)- & $112-80-1$ & 0.0023 & 0.0041 \\
\hline 114 & 9-Octadecenoic acid, (Z)- & $112-80-1$ & 0.00064 & 0.00112 \\
\hline 115 & 9-Octadecenoic acid, (Z)- & $112-80-1$ & 0.0036 & 0.0063 \\
\hline 118 & 9-Octadecenoic acid, methyl ester (E) & $1937-62-8$ & 0.0055 & 0.0050 \\
\hline 13 & Acetic acid & $64-19-7$ & 0.16 & 0.17 \\
\hline 14 & Acetic acid & $64-19-7$ & 0.067 & 0.115 \\
\hline 17 & Acetic acid & $64-19-7$ & 0.031 & 0.053 \\
\hline 121 & Alkane and Alkanoic acid & & 0.0011 & 0.0019 \\
\hline 127 & Alkane & & 0.0054 & 0.0093 \\
\hline 105 & Alkanone & & 0.0015 & 0.0013 \\
\hline 41 & Alkenol & & 0.0050 & 0.0087 \\
\hline 79 & alkyl-cyclopentane & & 0.0017 & 0.0029 \\
\hline 80 & alkyl nitrile & & 0.019 & 0.004 \\
\hline 117 & Benzamide, N-methyl & $613-93-4$ & 0.00079 & 0.0014 \\
\hline 30 & Benzene, ethyl & $100-41-4$ & 0.0013 & 0.0022 \\
\hline 31 & Benzene, 1,2-dimethyl & $95-47-6$ & 0.0036 & 0.0031 \\
\hline 75 & Benzene, 1-chloro-4-nitro & $100-00-5$ & 0.0052 & 0.0011 \\
\hline 62 & Benzeneacetic acid, a-4-bis[(trimethylsilyl) & $37148-64-4$ & 0.0047 & 0.0042 \\
\hline 123 & Benzenesulfonamide, N-butyl & $3622-84-2$ & 0.091 & 0.015 \\
\hline 7 & Butane, 1-chloro & $109-69-3$ & 0.030 & 0.006 \\
\hline 33 & Butane, 2-bromo & 78-76-2 & 0.0034 & 0.0059 \\
\hline 107 & $\begin{array}{l}\text { Butyric acid, ester w/ } \\
\text { p-hydroxybenzonitrile }\end{array}$ & $29052-10-6$ & 0.00094 & 0.00162 \\
\hline 99 & Cyclohexadecane & $295-65-8$ & 0.0019 & 0.0019 \\
\hline 92 & Cyclohexanone, 4-hydroxy-4-methyl & $17429-02-6$ & 0.00082 & 0.00142 \\
\hline
\end{tabular}


WHC-SD-WM-ER-445 Rev. 1

\begin{tabular}{|c|c|c|c|c|}
\hline Cmpd & Compound & $\begin{array}{l}\text { CAS }^{1} \\
\text { Number }\end{array}$ & $\begin{array}{l}\text { Average }^{2} \\
\left(\mathrm{mg} / \mathrm{m}^{3}\right)\end{array}$ & $\begin{array}{c}\text { Standard } \\
\text { Deviation } \\
\left(\mathrm{mg} / \mathrm{m}^{3}\right) \\
\end{array}$ \\
\hline 63 & Cyclohexanone,2,5-dimethyl-2-(1-methyle & $6711-26-8$ & 0.0011 & 0.0020 \\
\hline 18 & Cyclopropane, 1,2-dimethyl, cis & $930-18-7$ & 0.011 & 0.010 \\
\hline 54 & Cyclopropane, pentyl & $2511-91-3$ & 0.0015 & 0.0026 \\
\hline 8 & Cyclopropanecarbonitrile & $5500-21-0$ & 0.0072 & 0.0124 \\
\hline 46 & Cyclotetrasiloxane, octamethyl & $556-67-2$ & 0.060 & 0.037 \\
\hline 25 & Cyclotrisiloxane, hexamethyl & $541-05-9$ & 0.27 & 0.23 \\
\hline 73 & Decanal & $112-31-2$ & 0.0089 & 0.0010 \\
\hline 65 & Decane, 2-methyl & $6975-98-0$ & 0.0078 & 0.0067 \\
\hline 86 & Decane, 5-propyl- and others & & 0.013 & 0.003 \\
\hline 100 & Dodecanoic acid & $143-07-7$ & 0.014 & 0.002 \\
\hline 124 & Eicosane & $112-95-8$ & 0.0042 & 0.0074 \\
\hline 137 & Eicosane & $112-95-8$ & 0.0014 & 0.0025 \\
\hline 55 & Ethanone, 1-phenyl & $98-86-2$ & 0.0049 & 0.0045 \\
\hline 20 & Ethene, 1,1'-oxybis & $109-93-3$ & 0.0056 & 0.0097 \\
\hline 21 & Ethene, 1,1'-oxybis & $109-93-3$ & 0.027 & 0.047 \\
\hline 144 & Heneicosane & $629-94-7$ & 0.0043 & 0.0075 \\
\hline 113 & Heptadecane, 8-methyl & $13287-23-5$ & 0.00069 & 0.00119 \\
\hline 143 & Heptadecane, 2,6,10,15-tetramethyl & $54833-48-6$ & 0.0025 & 0.0044 \\
\hline 34 & Heptanal & $111-71-7$ & 0.0048 & 0.0005 \\
\hline 122 & $\begin{array}{l}\text { Hexadecanoic acid, } \\
\text { 2,3-dihydroxypropyles }\end{array}$ & $542-44-9$ & 0.0027 & 0.0023 \\
\hline 136 & Hexadecanoic acid & $57-10-3$ & 0.12 & 0.06 \\
\hline 140 & Hexadecanoic acid & $57-10-3$ & 0.024 & 0.006 \\
\hline 23 & Hexanal & $66-25-1$ & 0.0045 & 0.0078 \\
\hline 10 & Hexane, 2,3-dimethyl & $584-94-1$ & 0.0048 & 0.0083 \\
\hline 39 & Hexane 3,4-dimethyl and others & & 0.0032 & 0.0029 \\
\hline 111 & Hexanedioic acid, bis-(1-methylpropyl)-est & $38447-22-2$ & 0.00064 & 0.00111 \\
\hline 128 & Hexanedioic acid, dioctyl ester & $123-79-5$ & 0.047 & 0.081 \\
\hline
\end{tabular}




\begin{tabular}{|c|c|c|c|c|}
\hline $\begin{array}{c}\text { Cmpd } \\
\#\end{array}$ & Compound & $\begin{array}{c}\mathrm{CAS}^{1} \\
\text { Number }\end{array}$ & $\begin{array}{c}\text { Average }^{2} \\
\left(\mathrm{mg} / \mathrm{m}^{3}\right)\end{array}$ & $\begin{array}{c}\text { Standard } \\
\text { Deviation } \\
\left(\mathrm{mg} / \mathrm{m}^{3}\right)\end{array}$ \\
\hline 1 & Methane, oxybis & $115-10-6$ & 0.044 & 0.012 \\
\hline 2 & Methane, trichlorofluoro & $75-69-4$ & 0.049 & 0.039 \\
\hline 28 & Methylamine, N-(1-methylbutylidene)- & $22431-09-0$ & 0.0061 & 0.0106 \\
\hline 12 & Mixture & & 0.0063 & 0.0056 \\
\hline 37 & Mixture & & 0.0016 & 0.0027 \\
\hline 44 & Mixture & & 0.0019 & 0.0033 \\
\hline 102 & Mixture & & 0.0022 & 0.0020 \\
\hline 106 & Mixture & & 0.00095 & 0.00164 \\
\hline 71 & Naphthalene & $91-20-3$ & 0.0010 & 0.0017 \\
\hline 6 & Nitric acid, ethyl ester & $625-58-1$ & 0.051 & 0.010 \\
\hline 11 & Nitric acid, propyl ester & $627-13-4$ & 0.0057 & 0.0099 \\
\hline 26 & Nitric acid, propyl ester & $627-13-4$ & 0.019 & 0.017 \\
\hline 27 & Nitric acid, butyl ester & $928-45-0$ & 0.0039 & 0.0067 \\
\hline 48 & Nitric acid, butyl ester & $928-45-0$ & 0.010 & 0.003 \\
\hline 61 & Nitric acid, hexyl ester & $20633-11-8$ & 0.0081 & 0.0007 \\
\hline 3 & nitro compound & & 0.021 & 0.020 \\
\hline 134 & Nonadecane & $629-92-5$ & 0.00087 & 0.00152 \\
\hline 59 & Nonanal & $124-19-6$ & 0.011 & 0.001 \\
\hline 67 & Nonanenitrile & $2243-27-8$ & 0.017 & 0.009 \\
\hline 47 & Octanal & $124-13-0$ & 0.0082 & 0.0016 \\
\hline 56 & Octanenitrile & $124-12-9$ & 0.021 & 0.006 \\
\hline 22 & Oxirane, etheny! & $930-22-3$ & 0.019 & 0.002 \\
\hline 145 & Pentadecane, 8-hexyl & $13475-75-7$ & 0.0035 & 0.0061 \\
\hline 130 & Pentadecanoic acid & $1002-84-2$ & 0.029 & 0.026 \\
\hline 43 & Phenol and 1-propenyl benzene & & 0.0034 & 0.0059 \\
\hline 108 & Phthalate & & 0.0055 & 0.0056 \\
\hline 16 & Propane, 2-methyl-2-nitro & $594-70-7$ & 0.034 & 0.030 \\
\hline 24 & Propane, 2-methyl-2-nitro & $594-70-7$ & 0.015 & 0.003 \\
\hline
\end{tabular}




\section{WHC-SD-WM-ER-445 Rev. 1}

\begin{tabular}{clccc}
\hline $\begin{array}{c}\text { Cmpd } \\
\#\end{array}$ & Compound & $\begin{array}{c}\text { CAS }^{1} \\
\text { Number }\end{array}$ & $\begin{array}{c}\text { Average } \\
\left(\mathrm{mg} / \mathrm{m}^{3}\right)\end{array}$ & $\begin{array}{c}\text { Standard } \\
\text { Deviation } \\
\left(\mathrm{mg} / \mathrm{m}^{3}\right)\end{array}$ \\
\hline \hline 29 & Pyrazine, methyl & $109-08-0$ & 0.0033 & 0.0057 \\
90 & Tetradecane & $629-59-4$ & 0.025 & 0.005 \\
116 & Tetradecanoic acid & $544-63-8$ & 0.031 & 0.051 \\
119 & Tetradecanoic acid & $544-63-8$ & 0.057 & 0.049 \\
125 & Tetradecanoic acid, 12-methyl, cis & $5746-58-7$ & 0.0063 & 0.0054 \\
109 & Tributyl phosphate and benzenamine, & & 0.0068 & 0.0028 \\
& N-phenyl & & & 0.00114 \\
84 & Tridecanal & $10486-19-8$ & 0.00066 & 0.00112 \\
\hline \hline
\end{tabular}

$1 \mathrm{CAS}=$ Chemical Abstract Service.

2 Average of 3, 2-L TST samples; presented values are estimates. 
WHC-SD-WM-ER-445 Rev. 1

Table 4-9

Tank C-107 Tentatively Identified Organic Compounds in TST Samples Sorted by Estimated Concentration -Analyses by Oak Ridge National Laboratory

\begin{tabular}{|c|c|c|c|c|}
\hline Cmpd & Compound & $\begin{array}{c}\text { CAS }^{1} \\
\text { Number }\end{array}$ & $\begin{array}{c}\text { Average }^{2} \\
\left(\mathrm{mg} / \mathrm{m}^{3}\right)\end{array}$ & $\begin{array}{c}\text { Standard } \\
\text { Deviation } \\
\left(\mathrm{mg} / \mathrm{m}^{3}\right)\end{array}$ \\
\hline 25 & Cyclotrisiloxane, hexamethyl & $541-05-9$ & 0.27 & 0.23 \\
\hline 13 & Acetic acid & $64-19-7$ & 0.16 & 0.17 \\
\hline 136 & Hexadecanoic acid & $57-10-3$ & 0.12 & 0.06 \\
\hline 123 & Benzenesulfonamide, $\mathrm{N}$-butyl & $3622-84-2$ & 0.091 & 0.015 \\
\hline 135 & 9-Hexadecenoic acid & $2091-29-4$ & 0.090 & 0.009 \\
\hline 14 & Acetic acid & $64-19-7$ & 0.067 & 0.115 \\
\hline 46 & Cyclotetrasiloxane, octamethyl & $556-67-2$ & 0.060 & 0.037 \\
\hline 119 & Tetradecanoic acid & $544-63-8$ & 0.057 & 0.049 \\
\hline 6 & Nitric acid, ethyl ester & $625-58-1$ & 0.051 & 0.010 \\
\hline 2 & Methane, trichlorofluoro & $75-69-4$ & 0.049 & 0.039 \\
\hline 128 & Hexanedioic acid, dioctyl ester & $123-79-5$ & 0.047 & 0.081 \\
\hline 1 & Methane, oxybis & $115-10-6$ & 0.044 & 0.012 \\
\hline 141 & 1-Hexadecanol & $36653-82-4$ & 0.043 & 0.038 \\
\hline 16 & Propane, 2-methyl-2-nitro & $594-70-7$ & 0.034 & 0.030 \\
\hline 116 & Tetradecanoic acid & $544-63-8$ & 0.031 & 0.051 \\
\hline 17 & Acetic acid & $64-19-7$ & 0.031 & 0.053 \\
\hline 7 & Butane, 1-chloro & $109-69-3$ & 0.030 & 0.006 \\
\hline 130 & Pentadecanoic acid & $1002-84-2$ & 0.029 & 0.026 \\
\hline 142 & 1-Octadecanol & $112-92-5$ & 0.027 & 0.046 \\
\hline 21 & Ethene, $1,1^{\prime}$-oxybis & $109-93-3$ & 0.027 & 0.047 \\
\hline 90 & Tetradecane & $629-59-4$ & 0.025 & 0.005 \\
\hline 140 & Hexadecanoic acid & $57-10-3$ & 0.024 & 0.006 \\
\hline 3 & nitro compound & & 0.021 & 0.020 \\
\hline 56 & Octanenitrile & $124-12-9$ & 0.021 & 0.006 \\
\hline 22 & Oxirane, ethenyl & $930-22-3$ & 0.019 & 0.002 \\
\hline 26 & Nitric acid, propyl ester & $627-13-4$ & 0.019 & 0.017 \\
\hline
\end{tabular}


WHC-SD-WM-ER-445 ReV. 1

\begin{tabular}{|c|c|c|c|c|}
\hline$\underset{\#}{\text { Cmpd }}$ & Compound & $\begin{array}{l}\text { CAS }^{1} \\
\text { Number }\end{array}$ & $\begin{array}{l}\text { Average } \\
\left(\mathrm{mg} / \mathrm{m}^{3}\right)\end{array}$ & $\begin{array}{c}\text { Standard } \\
\text { Deviation } \\
\left(\mathrm{mg} / \mathrm{m}^{3}\right)\end{array}$ \\
\hline 80 & alkyl nitrile & & 0.019 & 0.004 \\
\hline 67 & Nonanenitrile & $2243-27-8$ & 0.017 & 0.009 \\
\hline 24 & Propane, 2-methyl-2-nitro & $594-70-7$ & 0.015 & 0.003 \\
\hline 100 & Dodecanoic acid & $143-07-7$ & 0.014 & 0.002 \\
\hline 86 & Decane, 5-propyl-and others & & 0.013 & 0.003 \\
\hline 89 & 3-Dodecanone & $1534-27-6$ & 0.013 & 0.0026 \\
\hline 78 & 5-Undecanone & $33083-83-9$ & 0.012 & 0.003 \\
\hline 94 & 5-Undecanone, 2-methyl & $50639-02-6$ & 0.012 & 0.002 \\
\hline 15 & 1-Pentene & $109-67-1$ & 0.011 & 0.019 \\
\hline 18 & Cyclopropane, 1,2-dimethyl, cis & $930-18-7$ & 0.011 & 0.010 \\
\hline 59 & Nonanal & $124-19-6$ & 0.011 & 0.001 \\
\hline 96 & 3-Tridecanone & $1534-26-5$ & 0.011 & 0.002 \\
\hline 48 & Nitric acid, butyl ester & $928-45-0$ & 0.010 & 0.003 \\
\hline 133 & 1-Octadecanol & $112-92-5$ & 0.0089 & 0.015 \\
\hline 73 & Decanal & $112-31-2$ & 0.0089 & 0.0010 \\
\hline 5 & 2-Butanone & $78-93-3$ & 0.0089 & 0.0154 \\
\hline 97 & 2-Tridecanone & $593-08-8$ & 0.0084 & 0.0065 \\
\hline 120 & 1-Hexadecanol & $36653-82-4$ & 0.0083 & 0.014 \\
\hline 64 & 2(3H)-Furanone, dihydro-5-propyl & $105-21-5$ & 0.0082 & 0.0018 \\
\hline 47 & Octanal & $124-13-0$ & 0.0082 & 0.0016 \\
\hline 61 & Nitric acid, hexyl ester & $20633-11-8$ & 0.0081 & 0.0007 \\
\hline 4 & 1-Propene, 2-fluoro and others & & 0.0080 & 0.0140 \\
\hline 65 & Decane, 2-methyl & $6975-98-0$ & 0.0078 & 0.0067 \\
\hline 95 & $\begin{array}{l}\text { 2,5-Cyclohexadiene, 1,4-dione, } \\
2,6 \text {-bis }(1,1\end{array}$ & $719-22-2$ & 0.0077 & 0.0025 \\
\hline 81 & 2-Undecanone & $112-12-9$ & 0.0076 & 0.0025 \\
\hline 85 & 6-Dodecanone & $6064-27-3$ & 0.0072 & 0.0024 \\
\hline 8 & Cyclopropanecarbonitrile & $5500-21-0$ & 0.0072 & 0.0124 \\
\hline 93 & 5,9-Undecadien-2-one,6,10-dimethyl (Z) & $3879-26-3$ & 0.0069 & 0.0029 \\
\hline
\end{tabular}


WHC-SD-WM-ER-445 Rev. 1

\begin{tabular}{|c|c|c|c|c|}
\hline$\underset{\#}{\text { Cmpd }}$ & Compound & $\begin{array}{l}\text { CAS }^{1} \\
\text { Number }\end{array}$ & $\begin{array}{l}\text { Average }{ }^{2} \\
\left(\mathrm{mg} / \mathrm{m}^{3}\right)\end{array}$ & $\begin{array}{c}\text { Standard } \\
\text { Deviation } \\
\left(\mathrm{mg} / \mathrm{m}^{3}\right)\end{array}$ \\
\hline 109 & $\begin{array}{l}\text { Tributyl phosphate and benzenamine, } \\
\text { N-phenyl }\end{array}$ & & 0.0068 & 0.0028 \\
\hline 131 & 1-Hexadecanol & $36653-82-4$ & 0.0068 & 0.0061 \\
\hline 68 & 4-Dodecene & $7206-15-7$ & 0.0068 & 0.0023 \\
\hline 129 & 14-Pentadecenoic acid & $17351-34-7$ & 0.0067 & 0.0069 \\
\hline 12 & Mixture & & 0.0063 & 0.0056 \\
\hline 125 & Tetradecanoic acid, 12-methyl, cis & $5746-58-7$ & 0.0063 & 0.0054 \\
\hline 28 & Methylamine, N-(1-methylbutylidene)- & $22431-09-0$ & 0.0061 & 0.0106 \\
\hline 58 & 2-Nonanone & $821-55-6$ & 0.0060 & 0.0053 \\
\hline 70 & 2-Decanone & $693-54-9$ & 0.0059 & 0.0008 \\
\hline 11 & Nitric acid, propyl ester & $627-13-4$ & 0.0057 & 0.0099 \\
\hline 20 & Ethene, $1,1^{\prime}$-oxybis & $109-93-3$ & 0.0056 & 0.0097 \\
\hline 118 & 9-Octadecenoic acid, methyl ester (E) & $1937-62-8$ & 0.0055 & 0.0050 \\
\hline 108 & Phthalate & & 0.0055 & 0.0056 \\
\hline 127 & Alkane & & 0.0054 & 0.0093 \\
\hline 75 & Benzene, 1-chloro-4-nitro & $100-00-5$ & 0.0052 & 0.0011 \\
\hline 41 & Alkenol & & 0.0050 & 0.0087 \\
\hline 55 & Ethanone, 1-phenyl & $98-86-2$ & 0.0049 & 0.0045 \\
\hline 10 & Hexane, 2,3-dimethyl & $584-94-1$ & 0.0048 & 0.0083 \\
\hline 34 & Heptanal & $111-71-7$ & 0.0048 & 0.0005 \\
\hline 62 & Benzeneacetic acid, a-4-bis[(trimethylsilyl) & $37148-64-4$ & 0.0047 & 0.0042 \\
\hline 23 & Hexanal & $66-25-1$ & 0.0045 & 0.0078 \\
\hline 132 & 1-Hexadecene & $629-73-2$ & 0.0043 & 0.0075 \\
\hline 144 & Heneicosane & $629-94-7$ & 0.0043 & 0.0075 \\
\hline 124 & Eicosane & $112-95-8$ & 0.0042 & 0.0074 \\
\hline 66 & 5-Undecanone, 2-methyl & $50639-02-6$ & 0.0041 & 0.0071 \\
\hline 19 & 1H-Pyrrole & $109-97-7$ & 0.0040 & 0.0070 \\
\hline 35 & 1,5-Pentanediol, dinitrate & $3457-92-9$ & 0.0040 & 0.0003 \\
\hline 27 & Nitric acid, butyl ester & $928-45-0$ & 0.0039 & 0.0067 \\
\hline
\end{tabular}




\begin{tabular}{|c|c|c|c|c|}
\hline$\underset{\#}{\text { Cmpd }}$ & Compound & $\begin{array}{l}\text { CAS }^{1} \\
\text { Number }\end{array}$ & $\begin{array}{l}\text { Average }^{2} \\
\left(\mathrm{mg} / \mathrm{m}^{3}\right)\end{array}$ & $\begin{array}{c}\text { Standard } \\
\text { Deviation } \\
\left(\mathrm{mg} / \mathrm{m}^{3}\right) \\
\end{array}$ \\
\hline 60 & 1,3-Benzenediol, 2-methyl & $608-25-3$ & 0.0037 & 0.0033 \\
\hline 115 & 9-Octadecenoic acid, (Z)- & $112-80-1$ & 0.0036 & 0.0063 \\
\hline 31 & Benzene, 1,2-dimethyl & $95-47-6$ & 0.0036 & 0.0031 \\
\hline 145 & Pentadecane, 8-hexyl & $13475-75-7$ & 0.0035 & 0.0061 \\
\hline 33 & Butane, 2-bromo & $78-76-2$ & 0.0034 & 0.0059 \\
\hline 50 & 3-Hexene-2-one and others & & 0.0034 & 0.0029 \\
\hline 51 & 2(3H)-Furanone, 5-ethyldihydro & $695-06-7$ & 0.0034 & 0.0030 \\
\hline 43 & Phenol and 1-propenyl benzene & & 0.0034 & 0.0059 \\
\hline 29 & Pyrazine, methyl & $109-08-0$ & 0.0033 & 0.0057 \\
\hline 101 & 5-Undecanone, 2-methyl & $50639-02-6$ & 0.0033 & 0.0008 \\
\hline 52 & $2 \mathrm{H}$-pyran-3(4H)-one, dihydro & $23462-75-1$ & 0.0032 & 0.0028 \\
\hline 39 & Hexane 3,4-dimethyl and others & & 0.0032 & 0.0029 \\
\hline 139 & 1-Hexadecanol, acetate & $629-70-9$ & 0.0030 & 0.0028 \\
\hline 72 & 4-Dodecene, cis=trans & & 0.0029 & 0.0031 \\
\hline 76 & 2(3H)-furanone, 5-butyldihydro & $104-50-7$ & 0.0028 & 0.0027 \\
\hline 38 & 2-Heptanone, 6-methyl & $928-68-7$ & 0.0027 & 0.0024 \\
\hline 122 & $\begin{array}{l}\text { Hexadecanoic acid, } \\
\text { 2,3-dihydroxypropyles }\end{array}$ & $542-44-9$ & 0.0027 & 0.0023 \\
\hline 74 & 1,3-Benzodioxal-2-one, hexahydro & $20192-66-9$ & 0.0025 & 0.0004 \\
\hline 9 & 2-Butanenitrile and others & & 0.0025 & 0.0044 \\
\hline 143 & Heptadecane, 2,6,10,15-tetramethyl & $54833-48-6$ & 0.0025 & 0.0044 \\
\hline 138 & 1-Hexadecanol & $36653-82-4$ & 0.0025 & 0.0044 \\
\hline 91 & 3-Octen-2-ol, 2-methyl, cis & $18521-07-8$ & 0.0024 & 0.0021 \\
\hline 77 & 1,3,5,7-Tetraazatricyclo[3.3.1.13.7]decane & $100-97-0$ & 0.0023 & 0.0040 \\
\hline 126 & 9-Octadecenoic acid, (Z)- & $112-80-1$ & 0.0023 & 0.0041 \\
\hline 45 & 5-Hepten-2-one, 6-methyl & $110-93-0$ & 0.0023 & 0.0040 \\
\hline 102 & Mixture & & 0.0022 & 0.0020 \\
\hline 32 & 3-Heptanone & $106-35-4$ & 0.0022 & 0.0038 \\
\hline 99 & Cyclohexadecane & $295-65-8$ & 0.0019 & 0.0019 \\
\hline
\end{tabular}


WHC-SD-WM-ER-445 Rev. 1

\begin{tabular}{|c|c|c|c|c|}
\hline$\underset{\#}{\text { Cmpd }}$ & Compound & $\begin{array}{l}\text { CAS }^{1} \\
\text { Number }\end{array}$ & $\begin{array}{l}\text { Average }{ }^{2} \\
\left(\mathrm{mg} / \mathrm{m}^{3}\right)\end{array}$ & $\begin{array}{l}\text { Standard } \\
\text { Deviation } \\
\left(\mathrm{mg} / \mathrm{m}^{3}\right)\end{array}$ \\
\hline 44 & Mixture & & 0.0019 & 0.0033 \\
\hline 42 & 4-Octanone & $589-63-9$ & 0.0017 & 0.0030 \\
\hline 79 & alkyl-cyclopentane & & 0.0017 & 0.0029 \\
\hline 69 & 1-Dodecene & $112-41-4$ & 0.0016 & 0.0029 \\
\hline 37 & Mixture & & 0.0016 & 0.0027 \\
\hline 49 & 1-Hexanol, 2-ethyl & $104-76-7$ & 0.0015 & 0.0026 \\
\hline 53 & 4-Nonanone & $4485-09-0$ & 0.0015 & 0.0026 \\
\hline 105 & Alkanorie & & 0.0015 & 0.0013 \\
\hline 54 & Cyclopropane, pentyl & $2511-91-3$ & 0.0015 & 0.0026 \\
\hline 137 & Eicosane & $112-95-8$ & 0.0014 & 0.0025 \\
\hline 110 & 3-Phenoxybenzaldehyde & $39515-51-0$ & 0.0014 & 0.0012 \\
\hline 57 & 4-Undecene, $(E)-$ & $693-62-9$ & 0.0014 & 0.0023 \\
\hline 36 & 2(3H)-furanone, dihydro and C3-benzene & & 0.0013 & 0.0022 \\
\hline 30 & Benzene, ethyl & $100-41-4$ & 0.0013 & 0.0022 \\
\hline 98 & 2-Pentene, 5-(pentyloxy)- (E)- & $56052-85-8$ & 0.0013 & 0.0023 \\
\hline 40 & 2(3H)-Furanone, dihydro-5-methyl & $108-29-2$ & 0.0012 & 0.0020 \\
\hline 121 & Alkane and Alkanoic acid & & 0.0011 & 0.0019 \\
\hline 63 & $\begin{array}{l}\text { Cyclohexanone,2,5-dimethyl-2-(1-methyle } \\
\text { t }\end{array}$ & $6711-26-8$ & 0.0011 & 0.0020 \\
\hline 88 & 3-Octanone & $106-68-3$ & 0.0010 & 0.0018 \\
\hline 71 & Naphthalene & $91-20-3$ & 0.0010 & 0.0017 \\
\hline 106 & Mixture & & 0.00095 & 0.00164 \\
\hline 107 & $\begin{array}{l}\text { Butyric acid, ester w/ } \\
\text { p-hydroxybenzonitrile }\end{array}$ & $29052-10-6$ & 0.00094 & 0.00162 \\
\hline 87 & 1H-Inden-1-one, 2,3-dihydro-3,3-dimethyl & $26465-81-6$ & 0.00098 & 0.0017 \\
\hline 134 & Nonadecane & $629-92-5$ & 0.00087 & 0.00152 \\
\hline 82 & 1-Tridecene & $2437-56-1$ & 0.00080 & 0.00139 \\
\hline 92 & Cyclohexanone, 4-hydroxy-4-methyl & $17429-02-6$ & 0.00082 & 0.00142 \\
\hline 117 & Benzamide, N-methyl & $613-93-4$ & 0.00079 & 0.0014 \\
\hline
\end{tabular}


WHC-SD-WM-ER-445 Rev. 1

\begin{tabular}{clrrr}
\hline $\begin{array}{c}\text { Cmpd } \\
\#\end{array}$ & Compound & $\begin{array}{c}\text { CAS } \\
\text { Number }\end{array}$ & $\begin{array}{c}\text { Average } \\
\left(\mathrm{mg}^{2} / \mathrm{m}^{3}\right)\end{array}$ & $\begin{array}{c}\text { Standard } \\
\text { Deviation } \\
\left(\mathrm{mg} / \mathrm{m}^{3}\right)\end{array}$ \\
\hline \hline 112 & 1-Dodecanol & $112-53-8$ & 0.00073 & 0.00127 \\
83 & 1-Tridecene & $2437-56-1$ & 0.00070 & 0.00122 \\
113 & Heptadecane, 8-methyl & $13287-23-5$ & 0.00069 & 0.00119 \\
104 & Undecane, 3,8-dimethy) & $17301-30-3$ & 0.00065 & 0.00112 \\
103 & 3-Dodecanone & $1534-27-6$ & 0.00064 & 0.00110 \\
111 & Hexanedioic acid, bis-(1-methylpropyl)-est & $38447-22-2$ & 0.00064 & 0.00111 \\
114 & 9-Octadecenoic acid, (Z)- & $112-80-1$ & 0.00064 & 0.00112 \\
84 & Tridecanal & $10486-19-8$ & 0.00066 & 0.00114 \\
\hline Sum of tentatively identified compounds: & & 2.04 & \\
\hline \hline
\end{tabular}

$1 \mathrm{CAS}=$ Chemical Abstract Service.

2 Average of 3, 2-L TST samples; presented values are estimates. 
